\title{
Citizens and Soldiers in Archaic Athens
}

\author{
Hans van Wees \\ (University College London)
}

In $457 \mathrm{BC}$, the Athenian assembly gave the general Myronides permission to conscript a force of citizen hoplites for an invasion of Boeotia. When some of the conscripts failed to muster at the appointed time and place, Myronides decided that these 'ignoble and cowardly' latecomers were not worth waiting for, so he crossed into Boeotia with only those men whose readiness to turn up promptly guaranteed that 'in war they would not abandon their assigned place (taxis)' (Diod. 11.81.4-6). They won the battle of Oinophyta and conquered Boeotia. Next year, the Athenians decided to send a fleet to attack the territory of Sparta itself, and allowed the general Tolmides to conscript a force of 1,000 hoplites. Tolmides told those liable for service that they were about to be conscripted 'but that it would be better to serve as a volunteer than to be seen to be coerced by enlistment'. As a result, thousands of volunteers turned up, and after also conscripting the number originally allocated to him, Tolmides set off with a force of 4,000 hoplites (Diod. 11.84.4), which raided Laconia and famously set fire to the Spartan dockyards. These two anecdotes not only represent the earliest campaigns about which we are explicitly told that they relied on selective conscription, ${ }^{1}$ but also neatly illustrate complex attitudes towards compulsory military service. On the one hand, a citizen who failed to do his military duty might well be allowed to get away with it rather face a court martial; on the other hand, a citizen was under moral pressure to do more than his minimal legal duty and to volunteer for additional service. ${ }^{2}$

Classical Athens struck a delicate balance in imposing military (and fiscal) obligations on its citizens by law while relying to a large extent, not on coercion, but on willingness to 'perform' one's roles as a citizen, and indeed on the eagerness of some citizens to go the extra mile and outperform their peers. ${ }^{3}$ Nevertheless, access to citizenship was regulated by formal procedures as well as by acceptance by the rest of the group; citizen rights and duties were stipulated in written law as well as agreed by convention; the rules could be enforced by institutional authorities applying legal sanctions, rather than by peer pressure only. Citizenship in classical Athens was a legal status and the citizens constituted an 'order' defined by law (Finley 1973, 47-51), rather than a 'status group' defined by peer interaction.

This 'order' of citizens did not exist from time immemorial but was the product of a long process of state-formation, which saw the gradual replacement of informal and personal

Thucydides' much briefer account of both campaigns (1.108) gives no details about conscripts or volunteers. A chronologically vague comment in Ath. Pol. 26.1 suggests that conscription had already been in use at Athens before 462 BC (as noted by Christ 2001, 399); the Themistocles Decree refers to non-selective conscription of naval crews in 480 BC (ML 23.23-5): see below, p. 000.

The insightful comments of Alain Duplouy and Roel Konijnendijk on a draft have helped me improve this chapter; any remaining failings in argument or errors of fact are my own.

2 For full and excellent discussion of the classical evidence for such attitudes, see Christ 2006, 45-142; Roisman 2005, 105-29. Christ, however, underestimates the role of volunteering: significantly, he tells the Myronides-story twice in detail (2006, 59, 93-4), but confines the Tolmides-story to a brief footnote (49 n. 14); elsewhere, he dismisses Plut. Per. 18.2 as merely 'a different version' of the Tolmides-story (Christ 2001, 399 n. 4), which it clearly is not: see further below at n. 80.

3 See also e.g. Gabrielsen 1994; Whitehead 1983, on the performance of liturgies. The role of 'performance' in the negotiation of status is brilliantly analysed by Duplouy 2006. 
power relations, fluid structures, moral obligations and peer pressure - typical of pre-state communities - by the kinds of formal and public power, institutional structures, legal rights and duties and judicial coercion that are characteristic of the developed State. In the earliest stages of the process, citizenship will not have been a meaningful concept, and other forms of identity and belonging were no doubt more significant; at later stages, when citizenship did come into existence, it may initially have taken forms quite different from its late fifth- and fourth-century incarnations. The challenge is to determine, despite the severe limitations of the evidence, when and how citizenship developed between c. 750 and 450 BC.

In tackling that challenge, a good deal of scholarship from the 1980s onwards right up to the present volume has taken the view that at Athens and across the Greek world at large, levels of state-formation remained very low until the late sixth or early fifth century, and by implication that citizenship remained an essentially fluid and informal status until the end of the archaic period. Specifically with regard to military obligations, it is widely held that at Athens a conscript army did not exist before the reforms of Cleisthenes in $508 \mathrm{BC}$, and that a public navy was not established until another 25 years later by the ship-building programme of Themistocles. Until then, any Athenian military activity is supposed to have been conducted on a personal, irregular and voluntary basis. ${ }^{4}$

This is not a tenable view, I would argue. While developments in state-formation do accelerate in the decades either side of $500 \mathrm{BC}$, it does not follow that in earlier centuries legal and institutional development was negligible, rather than merely a little less advanced. Contemporary inscriptions show that written law and formal political office existed from at least c. $650 \mathrm{BC}$ onwards. We have few details, but that is because the surviving contemporary material is so limited and, for our purposes, random: in the early archaic period absence of evidence cannot be taken as evidence of absence. As for Classical and Hellenistic authors who tell us about archaic laws and institutions, their terminology and interpretations are liable to be anachronistic and some of what they say may be mere speculation, but scholars have been too quick to dismiss these sources out of hand, or given themselves licence to accept or reject such later information to suit a preferred model of archaic history. Instead, we need to judge each piece of information on its own merits. Finally, it is fair to say, as Alain Duplouy does in the introduction to this volume, that traditional scholarship has given too much weight to the 'formalist' history of laws and institutions and not enough to the 'substantivist' analysis of individual performance, informal group dynamics and social networks (p. 000), but this does not mean that we should now concentrate on the latter to the exclusion of the former. We should investigate both the informal and the formal, legal, institutional aspects of citizenship.

On that basis, I hope to show in what follows that there was indeed a difference between archaic and classical Athenian citizenship in respect of military obligations, but that the difference lay not in greater informality and fluidity, but on the contrary in stricter legal regulation of military and other obligations for the social and political elite, as opposed to the majority of the population whose liability for military service was more limited. From Solon's reforms onwards, the distinctive archaic form of Athenian citizenship was membership in a hierarchical set of juridical 'orders' with precisely defined and differentiated rights and duties, whose significance faded only in the late fifth century with the rise of democratic government.

For the army, see e.g. Frost 1984; Christ 2001, 399; Pritchard 2010, 7-16; for the navy, see e.g. Haas 1984; Gabrielsen 1985; 1994, 26-37; 2007, 254-5; Wallinga 2005, 7-11; cf. Hale 2009, 8-20. 


\section{Oligarchy, democracy and civic military obligations}

The idea that citizenship might have been more stringently regulated in the sixth century than in the fourth century BC may seem counterintuitive, and to go against the tide of the process of state-formation, but a relative lack of regulation was regarded in antiquity as a typical feature of the kind of democratic regime that Athens developed. Under democracy, 'anyone can do what he likes' (Plato Rep. 557b), even in military matters. Thucydides gave the sentiment a positive spin in Pericles' Funeral Oration: whereas the Spartans create courage 'by laborious training', 'we have a relaxed lifestyle, yet we are no less prepared to go out and face equally great danger'; 'we are willing to face danger, not primarily due to law, but to our courageous character' $(2.39 .1,4)$. Plato offered a sarcastic variation on the theme when he said that 'such a way of life is wonderfully pleasant in the short term': 'there is no compulsion at all in such a city to govern, even if you are fit for government, nor to be governed, if you don't want to, nor to go to war when there is a war on, nor to keep the peace when the others do so' (557e). By the same token, a citizen in a democracy is free to dedicate himself to warfare on a whim 'if he seeks to emulate some warlike men' (561d). Plutarch tells a moralizing story about the people of democratic Tarentum who lived relaxed lives and ignored warnings that things would change if they accepted Pyrrhus and his army into the city: when Pyrrhus arrived, he imposed and enforced conscription so rigidly that many Tarentines chose to leave their city rather than live in 'slavery' (Pyr. 13-16.2). ${ }^{5}$

In contrast to the limits of state control over military training, equipment, mobilisation and discipline in democratic cities, oligarchic governments are credited with a greater degree of intervention. Plato's ideal state has compulsory military training (Laws 829a-31b), clear and stringent military regulations (see below), and a law that anyone who 'makes peace or war privately, without the community' will be punished by death (955c). Aristotle's Politics shows that 'oligarchic schemes in legislation' typically imposed strict control on the rich:

With regard to the assembly, all are allowed to take part in meetings, but if they do not attend only the rich are liable to a fine, or a much greater fine; with regard to magistracies, those who meet the property qualification (timema) are not allowed to exempt themselves under oath, but the poor are; with regard to the courts, there is a fine for the rich if they do not serve on the jury, but the poor are scot-free ...

In the same way they also legislate with regard to ownership of military equipment and exercise in the gymnasium (peri tou hopla kektesthai kai tou gumnazesthai): for the poor are allowed not to own any, but the rich who do not own any are liable to a fine, and if they do not exercise in the gymnasium there is no fine at all for the former, but the rich are liable to a fine so that they will take part on account of this fine, but the others will not take part because they have nothing to fear. (1297a17-35)

Note that the 'poor' (aporoi) are not excluded from political, judicial or military roles, but merely exempted from the obligation to serve, which is imposed only on the 'rich men' (euporoi) to balance their exclusive right to full political rights. When Aristotle goes on to say that in democracies 'they do the opposite', he means that there is no compulsion for anyone: no one is fined for avoiding assemblies or jury service but everyone is paid for fulfilling their civic duties (1297a36-9). Military duties are not even mentioned here.

From these fifth- and fourth-century characterisations of oligarchy and democracy we cannot necessarily infer that archaic regimes with restricted political participation operated in

Cf. Christ 2006, 63, citing some of these passages: Athens, 'in keeping with democratic values, stopped short of rigidly forcing its free citizens to comply with conscription'. For the very limited extent to which Greek cities organized military training in particular, see Van Wees 2004, 87-95. 
the same way as classical oligarchies - though they may have done - but we can conclude that the level of formal regulation of citizen duties in democratic Athens was exceptionally low by classical Greek standards. If we are to avoid the mistake of projecting classical conditions back into the archaic age, then, we should allow for the possibility that in lessdemocratic archaic Athens standards of regulation were higher rather than lower.

A peculiar feature of the military law of classical Athens hints that legislation was indeed more stringent once: one of its provisions was apparently no longer enforced in the fourth century. The law stipulated three offences:

Solon, the ancient lawgiver, believed that the draft-evader and the man who left his post and the coward alike must be liable to the same penalties ...

The lawgiver therefore forces the draft-evader and the coward and the man who leaves his post to keep outside the lustral basins of the agora, and does not allow him to be crowned with a wreath or to attend public sacred rites. (Aeschin. 3.175-6)

The same three offences head a list of crimes which according to Andocides were punishable by loss of citizen rights, without loss of property, before $403 \mathrm{BC}(1.74)$. They are said in a prosecution speech of $395 \mathrm{BC}$ to have been covered by a single statute:

$\mathrm{He}$ is the only citizen liable to the whole law, for he could rightly be convicted of draftevasion insofar as he did not march out amongst you despite having been listed as hoplite; [of leaving his post, insofar as in the infantry] ${ }^{6}$ army he alone did not present himself along with the others to be assigned a post; and of cowardice insofar as he chose to serve in the cavalry when he was obliged to face danger among the hoplites. (Lys. 14.7)

Although the accused, Alcibiades (Junior), is here said to be guilty of cowardice - and his defence countered that he was not (14.5) - the formal charge brought against him was not 'cowardice' (deilia), but 'draft-evasion' (astrateia, 15.1, 4) or 'leaving his post' (lipotaxion, 15.11). ${ }^{7}$ This is characteristic of fourth-century Athens, where rhetorical claims that one's opponent was a coward were frequently bandied about in court and assembly, but no one was actually prosecuted for cowardice, only for astrateia and lipotaxion.

The sole allusions to trials for cowardice at Athens occur in Aristophanes' comedies: Dicaeopolis in Acharnians (1129), and Paphlagon in Knights (368) are threatened with prosecution on this charge, which shows that in the early years of the Peloponnesian War (425 and $424 \mathrm{BC}$ ) this was at least conceivable. Two prosecutions from $330 \mathrm{BC}$ show that a century later this was no longer an option. The orator Lycurgus claimed that Leocrates was a coward $(1.130,132)$ and a traitor $(1.59,68,149)$ for leaving Athens after the battle of Chaeronea eight years earlier, but rather than prosecute him on these charges, he chose to accuse him of 'draft-evasion' (astrateia) and 'leaving his post' (lipotaxion, 1.147; cf. 1.8-9, 76-78). By Lycurgus' own admission, this stretched the interpretation of the law so far that it required the assembly to act as 'lawgivers' and set a new precedent (1.9) - yet he preferred this strained charge to a simple accusation of cowardice. In the same year, Aeschines, arguing that Demosthenes should lose his citizen-rights as punishment for alleged cowardice at Chaeronea, felt the need to explain the legal basis for this claim, citing the legislation of 'Solon, the ancient lawgiver', as quoted above, and commenting: reference to lipotaxion. The supplement adopted here is that of Thalheim 1877; Lipsius 1905, 454-5 n. 3 emended to 'lipotaxion, insofar as he did not present himself'; see Hamel 1998a, 366-76. 
'Yes, there are public suits for cowardice (graphai deilias). Some of you may be surprised that there are public suits against nature (phuseos). There are!' (Aeschin. 3.175).

He evidently assumed that his audience no longer thought of 'cowardice' as a meaningful category in law: they saw it as a generic character trait which could not in itself be liable to prosecution and was only an offence insofar as it took the form of specific kinds of behaviour, such as draft-evasion or leaving one's post.

Accordingly, the military regulations in Plato's Laws (943a-45b) do not include a law on cowardice in general, but only specific laws on draft-evasion, desertion, and throwing away one's shield, all in sharply defined circumstances (see below). Around the time Laws was completed, an Athenian expedition to Tamynae in Euboea apparently haemorrhaged manpower - perhaps because it was early in the year and many citizens were in a hurry to get back to Athens to celebrate the Dionysia festival - but all the charges brought in connection with this and earlier fourth-century campaigns were of draft-evasion or leaving one's post, not cowardice, and hardly any were seriously pursued or enforced. ${ }^{8}$ In 349 BC, Demosthenes went so far as to advocate a legal reform in order to improve Athens' military efficiency: 'some of the laws concerning those who go on campaign', he argued, should be repealed, because these 'make those who are disorderly go scot-free' (3.10-11).

Xenophon reflected this Athenian attitude a few decades earlier when he wrote that in Sparta cowards were made to suffer, but in 'other cities', 'when a man is proved a coward, the only consequence is that he is called a coward. He goes to the same market as the brave man, sits beside him, and frequents the same gymnasium, if he chooses' (Lac. Pol. 9.3-4). This statement may sound like a rhetorical exaggeration but is in fact very nearly true if, as we have suggested, 'cowardice' as such was no longer prosecuted, and other disciplinary offences, if prosecuted, were only haphazardly enforced, if at all. This brings us back full circle to the prosecution of Alcibiades in $395 \mathrm{BC}$, where we already see signs that the established law on military offences was no longer in tune with contemporary attitudes. Prosecution and defence debated what the law actually meant (14.5-6; see further below), and the prosecutor told the jury that they would be acting as 'lawgivers' insofar as their verdict would set a precedent for the future interpretation of the law (14.4). Moreover, the prosecutor anticipated that the jury would hesitate to convict because they felt that 'the law was too strong' and 'the punishment was too great', so on that point he changed tack and told the jurors that they were not lawgivers and should simply enforce the rules (15.9).

In short, a law regulating military discipline had been established before $403 \mathrm{BC}$ but was regarded as problematic by $395 \mathrm{BC}$ and barely enforced in the fourth century; its broadest offence, 'cowardice', was apparently no longer deemed a viable legal charge at all. A parallel development may be seen in the disciplinary powers of the generals and cavalry commanders, who, 'when they lead an expedition, have the authority to imprison a disorderly man (atakton) and to bar him from service and to impose a fine, but they do not usually impose fines' (Ath. Pol. 61.2, 4). Just as the legal obligations of the soldiers were not strictly enforced, the legal powers of the officers were not strictly applied in Aristotle's day, and we hear of some very

Tamynae, 348 BC: Plut. Phocion 12.3 (desertion a general problem; Phocion chooses to allow it); Dem. 39.16-17 (Boiotos charged with lipotaxion for staying in Athens to celebrate Dionysia, but apparently not punished: Dem. 40); Dem. 21.103 (Demosthenes charged with lipotaxion but prosecution dropped); Dem. 21.110, 164-6 (Meidias rhetorically accused of lipotaxion from cavalry; both Demosthenes and Meidias were back in Athens for the Dionysia). Three convictions for astrateia: Sannio the chorus trainer, and Aristides the chorus-leader (Dem. 21.58-9, 60; punishments not enforced); Xenocleides the poet ([Dem.] 59.27; atimia, exile). On limited enforcement of these laws, see Christ 2006, 59-63, 118-24; Van Wees 2004, 108-13. 
mildly punished instances of extreme indiscipline which suggest that the same was true already in the early fourth century. ${ }^{9}$

Fourth-century Athens thus had laws governing military obligations and discipline which were out of touch with common attitudes - attitudes exemplifying the 'laxity' in military and other matters that critics regarded as characteristic of democratic regimes. As suggested, then, we should not assume that the process of state-formation always entailed a linear development towards ever greater legal regulation of citizen duties: while the rules are likely to have become increasingly formal and precise, they did not necessarily become more comprehensive or demanding. ${ }^{10}$ We may further conclude that Athens' military laws must have been first enacted at a time when Athens was less democratic than it was in the fourth century. In all likelihood this will take us back to a time before the democratic reforms of Ephialtes and Pericles. The latest plausible date would be the reforms of Cleisthenes, but a closer look at the law will show that it may well date further back and could indeed be the work of 'Solon, the ancient lawgiver' to whom Aeschines attributed this legislation. ${ }^{11}$

\section{Civic military duties in classical and archaic law}

What exactly was the scope and purpose of military law in classical Athens? Most informative here is Andocides' list of offenders disenfranchised before $403 \mathrm{BC}$ :

All who left their post, or were convicted of astrateia or deilia or anaumachia, or threw away their shields, or were convicted of three times bearing false witness or three times issuing a false summons, or maltreated their parents - all of these were deprived of citizen rights (atimoi) but kept their property. (Andoc. 1.74)

We have already seen that the first three of these offences were covered by a single law, not three separate statutes, and that the third element, 'cowardice', was later regarded as too generic to be a viable basis of legal action, an aspect of a man's 'nature' rather than a form of illegal behaviour. The remaining two military offences, anaumachia ('failure to fight in naval battle'), and throwing away one's shield, might in principle have been liable to punishment under the same law, as forms of cowardice or 'leaving one's post', but the latter offence, at any rate, does seem to have been the subject of a separate law (see below).

The most striking feature of the law on astrateia - as I shall call it for convenience - is the very wide scope created by the inclusion of three named offences and reinforced by the vagueness of all three. The terms astrateia and lipotaxion were almost as ill-defined as

Notably the mere 'barring' of Simon for hitting a superior officer in 394 (Lys. 3.45, allegedly the only soldier on the entire campaign to be punished in this way); and the mere 'talking to' received by the drunk and disorderly sons of Conon (Dem. 54.4-5); see further Hamel 1998a, 59-63. We have two instances of Athenian generals with the power to execute soldiers, both of which date to the Peloponnesian War (Lys. 13.67; Xen. Hell. 1.1.15), and stand in contrast to the disapproval in the 390s of Iphicrates' action in stabbing a sentry (to death?) for falling asleep (Frontinus, Strat. 3.12.2). This may confirm a change in attitudes towards discipline, but on the other hand the earlier offences probably constituted treason rather than mere indiscipline.

10 I have argued elsewhere for a similar development in fiscal obligations: eisphora was levied on all three highest property classes under Solon, but the burden was shifted largely onto the highest two classes under Cleisthenes, then confined to the equivalent of the highest property class after 377/6 BC (Van Wees 2013b, 83-97). At the same time the laws and procedures involved no doubt became more complex, as in other areas of public finance (see Rhodes 2013; Fawcett, forthcoming 2016).

11 Aeschin. 3.175, as cited above; also Dem. 24.103. I accept of course that attributions by orators of Athenian laws to Solon have very little value as historical evidence. Conversely, it is also worth remembering that some archaic laws did remain valid in theory even though they were ignored in practice: see Ath. Pol. 8.1, 47.1 on the Treasurers of Athena. 
cowardice. Plato's Laws admittedly defined the two terms unambiguously as respectively draft-evasion and desertion, ${ }^{12}$ but normal Athenian usage was not so clear, and indeed Plato may have been responding to this lack of clarity. Astrateia literally means 'not serving in a campaign', and could be used for 'freedom from having to serve' ${ }^{13}$ as well as 'refusal to serve'; in principle therefore astrateia could cover any form of absence from the army. Lipotaxion was even more ambiguous, since the meaning of 'leaving one's post' depended on what 'post' (taxis) one had in mind: a man's individual position in a rank-and-file formation; his allocation to a unit or ship; his place in infantry, cavalry or navy. ${ }^{14}$ Even evading the draft altogether could be labelled lipotaxion. In 361 BC a decree of the Athenian assembly convicted of 'leaving their post' all trierarchs who had stayed at home and had hired substitutes to captain their ships (Dem. 51.8). Similarly, Boiotos was charged in 348 BC with lipotaxion because he failed to join the army and stayed in Athens (Dem. 39.16-17). ${ }^{15}$

In one exceptional passage, lipotaxion is much more narrowly defined - more narrowly even than by Plato. In the trial of Alcibiades, the defence offered a highly restrictive interpretation of the offence which was indignantly rejected by the prosecutor:

some have the nerve to say that no one could be charged with lipotaxion or cowardice because no battle has taken place, and the law commands that if a man leaves his post to go towards the rear on account of cowardice while the others are fighting, on that man the soldiers should sit in judgement (Lys. 14.5).

The text from 'if a man leaves his post...' onwards sounds as if it might be a direct quotation of the law, and accordingly it has been argued that lipotaxion was confined to leaving the ranks during battle. ${ }^{16}$ But this is impossible. First, it is contradicted by the examples already cited of lipotaxion being used as a term for draft-evasion, and by other law court speeches which clearly use the term in a much wider sense. ${ }^{17}$ Secondly, on this narrow reading the law would have imposed a penalty for flight from combat but bizarrely not for outright desertion from the army. ${ }^{18}$ Finally, if the scope of the offence was so clearly limited, the prosecutor in

Plato Laws 943a: astrateia 'when someone fails to appear due to some cowardice, without the generals letting him off'; 943cd: lipotaxion when a soldier on campaign 'leaves for home earlier than the officials in charge lead them back'.

13 Aristoph. Peace 526, noted by Lipsius 1905, 453.

14 See Echeverría 2008, 170-1; 2012, 305-6, for the meanings of taxis, and see below for examples.

15 Less compelling than actual convictions for the offence are rhetorical statements to the same effect: Demosthenes' claims that Meidias 'left his post' three times which includes him staying at home and sending a hired substitute to serve as trierarch (21.163; the other two occasions involve transfers from cavalry to navy, 21.161-2, and back again, 21.164-6). The orator Lycurgus argues that 'leaving one's post' includes not taking up one's post in the first place $(1.77,147)$.

16 Hamel 1998a; e.g. Lipsius 1905, 452, also thinks that the law is being cited verbatim, but suggests that the citation was incomplete and that there were other clauses: see below, n. 18 .

See evidence cited at and in n. 15. Cf. [Dem.] 50.63: a captain who leaves his ship and returns to Athens before his successor has arrived is 'leaving his post'. Hamel 1998a tries to explain away all these broader usages of lipotaxion as rhetorical tricks, but her arguments are unconvincing.

18 Lipsius 1905, 452/3 posited that the law had a separate clause, not cited, to cover this: 'hinzufügen dürfen wir zu den letzten Paragraphen: und wer das Heer ohne Befehl verlä $\beta t$ '. Hamel argues that there was in fact a separate offence of desertion, called l(e)ipostration (1998a, 364, 376, 399-403). However, our three references to this offence all refer to whole units or contingents abandoning campaigns, rather than individuals deserting: Hdt. 5.27 .2 (cities destroyed by Otanes for lipostratia during Darius' Scythian campaign); Thuc. 1.99 .1 (allied contingents abandoning Athenian campaigns); schol. ad Aristoph. Eq. 226 (Cleon bringing a charge of leipostration against the entire Athenian cavalry on an unknown occasion; the references to a graphe lipostratiou in Pollux 6.151; 8.40; schol. ad Thuc. 6.91 .7 may all refer to Cleon's charge, since this accusation can hardly have been very common). Other lexical references to lipostration throw no light on the precise meaning of the term (Hesych. s.v.; Suda s.v.; Lex. Seg. 276.33; all cited and discussed by Hamel 1998a, 399). 
Alcibiades' case could hardly have even considered arguing that Alcibiades' actions (Lys. $14.7 ; 15.6)$ - transferring himself from infantry to cavalry - qualified as lipotaxion and cowardice. Everything thus suggests that the prosecutor was right to insist that the law had a much wider scope, even if it also included retreat during combat: 'You hear, gentlemen of the jury, that the law applies to both those who retreat to the rear during battle and those who are not present in the infantry army'. ${ }^{19}$

We may conclude that lipotaxion and astrateia were broad terms which overlapped with one another and with 'cowardice', ${ }^{20}$ and that the law was so vaguely formulated that it was open to quite different, minimalist and maximalist, interpretations. I would suggest that the law was broad and repetitive in its terminology because it was intended to be comprehensive, to cover all conceivable military offences from draft-dodging to desertion via any lesser shortfall in meeting one's military obligations. Even acts of insubordination were potentially covered: we know that in Sparta, at any rate, disobedience to orders could be prosecuted as a form of 'cowardice' (Thuc. 5.72.1). If even the relatively hierarchical Spartans preferred to not to penalize insubordination as such but to focus on the cowardice that supposedly motivated disobedience, the same will have been true of the Athenians and other Greeks who adopted a more egalitarian view of military and political authority. The oath sworn by young men on first joining the Athenian militia, cited by Lycurgus in his discussion of 'leaving one's post' (1.77), said nothing about obeying orders but promised merely 'not to abandon the man who stands beside me'. ${ }^{21}$ The Athenian law on military offences surely took the same egalitarian approach and included insubordination along with other offences under the rubrics of 'leaving one's post' and 'cowardice'.

Even if Alcibiades' defence did not quote the law verbatim, its skewed paraphrase does offer an important clue to the nature of the law, insofar as it apparently said that 'if a man' committed any of a wide range of military offences 'the soldiers should sit in judgement' (Lys. 14.5). In other words, the purpose of the law was not to define an offence but to prescribe a procedure: it specified which court should deal with such cases. From Aeschines' reference to the law we know that it also specified a legal procedure, namely the public written charge ( graphe $\bar{e}$, as well as a penalty, namely loss of citizen rights (atimia) in the form of being banned from the agora and public sacrifices (3.175-6, cited above). These details of

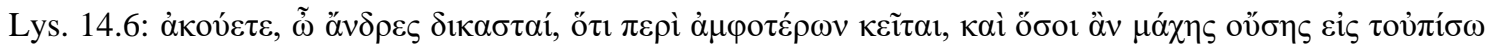

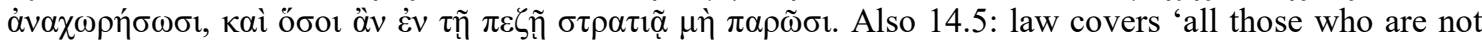
present in the infantry army'; 14.11: law also covers retreats during battle. The emphatic references to the infantry army were probably a sleight of hand: failure to serve as a hoplite was essential to the prosecution case, but the law probably used a generic term such as strateuein which included service in cavalry and navy as well.

20 The near-interchangeability of astrateia and lipotaxion explains how Alcibiades' prosecutor can bring 'a public charge of astrateia' $(15.1,4)$ yet sum up his case by saying that he has shown that Alcibiades 'left his post' (15.11); similarly, Dem. 39.16-17 refers to an accusation of lipotaxion which is apparently part of a public suit for astrateia. The overlap between the terms was noted by e.g. Todd 2000, 162; Carey 1989, 144; MacDowell 1962, 111; Lipsius 1905, 454; already in nineteenth-century scholarship cited by Hamel 1998a, 363 n. 7, who (wrongly) rejects this majority view.

21 Inscribed version: Tod II.204; RO 88; for structural differences between this oath and the more hierarchical Oath of Plataea, see Van Wees 2006a, 126-7. For the limits of hierarchy in Greek armies, see further e.g. Xen. Mem. 3.5.16; Hamel 1998b, 59-63; Hornblower 2000, 57-61, 72-3; Van Wees 2004, 108-12; Lendon 2005, 74-7; Christ 2006, 40-1, 95 n.16; Crowley 2012, 105-7. Plato's Laws did define astrateia and lipotaxion in hierarchical terms insofar as the offences explicitly entailed disobeying orders, but this definition reflected Plato's extraordinary enthusiasm for hierarchy (Laws 942ad) which was untypical of Greek attitudes. 
procedure and punishment are confirmed by other evidence. ${ }^{22}$ In its use of the public graphe and its allocation of jurisdiction to a popular court - the assembled soldiers - the astrateialaw featured the two key elements associated with Solon's legal reforms, and could thus in principle go back to Solon's day. ${ }^{23}$ Perhaps this law instituted for the first time a legal procedure for behaviour that had previously been punished by informal means; alternatively, it may merely have replaced an older legal procedure.

Of the two remaining military offences in Andocides' catalogue, anaumachia occurs in no other source, except later lexica which explicitly cite Andocides and define it as refusal by a ship's captain to take his vessel into action. ${ }^{24}$ This offence might have been subsumed under astrateia, deilia or lipotaxion, ${ }^{25}$ but was perhaps singled out for separate legislation because a captain's actions would have more dramatic consequences than individual cowardice: he could single-handedly prevent an entire crew of up to 200 men from taking part in battle.

'Throwing away one's shield' (tèn aspida apoballein), colloquially known also as 'flinging away one's shield' (tên aspida rhiptein), might also have been covered by 'cowardice', but it has generally been thought that this was made a distinct offence because it endangered the cohesion of the entire hoplite phalanx. The assumption is that one could not run with a hoplite shield but would drop it as soon as one turned to flight: the offence would thus have been the same as lipotaxion in the narrowest sense: retreating from combat. ${ }^{26}$ This is disproved, however, by Plato's insistence that losing one's equipment is often perfectly pardonable and that it is shameful and liable to punishment only in one particular set of circumstances, namely 'when a man is overtaken by the enemy and, although he is armed (echōn hopla), does not turn around to defend himself but voluntarily drops or throws away his equipment' (Laws 944c). Here, preserving the cohesion of the phalanx is clearly not the issue: the battle has already been lost, and a soldier in retreat or flight is about to be caught by a pursuing enemy. One might think that at this stage, with defeat already sealed, saving one's life at the cost of losing one's shield was a sensible option, as indeed the poets Archilochos and Alcaeus proclaimed (see below), and yet this is what the law forbade.

Moreover, the law seems to have referred not only to shields but to 'throwing away one's military equipment' (ta hopla). The passages in Lysias that referred primarily to the legal position, rather than to the act in battle, speak of 'the equipment' at large, not just the shield.

Soldiers constitute court, presided over by generals or taxiarchs: also Lys. 14.15, 17; 15.1-2; Dem. 39.17; cf. Plato Laws 943ac-945b. (ps-Xen. Ath. Pol. 3.5 has 'the people' judge cases arising from military campaigns.) Graphē: also Lys. 15.1 (astrateia; dike astrateias at Dem. 39.16); Dem. 21.103 (lipotaxion); Pollux 8.40 (lipotaxion and astrateia; cf. 6.151); Suda s.v. lipotaxion; cf. Plato Laws 943ad. Punishment is atimia: also And. 1.74; Dem. 21.58-60; 59.27. See Lipsius 1905, 112-14, 143, 452-4; Hamel 1998b, 634; Christ 2006, 59-60.

23 See Van Wees 2011 on the 'law of hybris' as genuinely Solonian; our military law is structurally similar to the hybris law in covering an entire category of offences (offences against the person; offences committed on campaign), and assigning these to a popular court via the graphe procedure.

24 So defined by Pollux 8.40, 42-3; other lexical references are Suda s.v. anaumachia and Lex. Seg. 217.21, both with explicit citation of Andocides (all entries quoted by Hamel 1998a, 403-4).

25 The words stratos and taxis applied to army and fleet equally, and accordingly so did astrateia and lipotaxion. A further offence, attested only in Pollux, is liponautia, 'deserting from one's ship', said to be the naval equivalent of lipotaxia and subject to a graphe $(8.40,42-3)$; given that liponautia does not feature in Andocides' apparently comprehensive list, it may not have been a distinct offence in law, but an informal term used by prosecutors who wished to be specific about what kind of lipotaxion they were alleging. The reference in [Dem.] 51.11 to trierarchs who 'bind and punish' crewmen who abandon their ship is presumably to an ad hoc measure, not to a legal procedure; oarsmen were usually hired, not drafted, and many were not citizens.

26 Full recent discussion: Schwartz 2009, esp. 147-55. Presumably the same assumptions underlie Pritchett's unsubstantiated claim that rhipsaspia was included under lipotaxion (1974, 233). 
Plato, too, in formulating an analogous law, spoke of ta hopla in the plural. ${ }^{27}$ In practice of course the shield was the heaviest and most awkward piece of equipment, the first or only thing to be jettisoned, but it is significant that these laws did not privilege it.

What emerges is not a law with a tactical purpose, but a law enshrining the supreme value of arms and armour, which a citizen must never surrender. Accordingly, a false accusation that a man had abandoned his arms was liable to be prosecuted under the law of slander, which tabooed this allegation as one of the most serious insults, along with 'murderer' and 'father- or mother-beater' (Lys. 10.6-9, 12) but not, so far as we can tell, with allegations that a man had failed in any other military duty. This confirms the particular shame attached to the offence. In the same vein, the first words of the oath of the Athenian ephebes were: 'I shall not shame the sacred arms' (ta hiera hopla; RO 88.6-7). For Plato, jettisoning one's equipment was a more shameful offence than draft-dodging or deserting, which in an ideal world would be punished by being turned into a woman (Laws $943 \mathrm{~d}-44 \mathrm{~b}){ }^{28}$

The principle that military equipment should never be given up extended beyond the battlefield: archaic laws banned handing over arms and armour as security for loans.

Not without reason some blame the majority of Greek lawgivers, who prohibited taking as security for a loan military equipment and the plough and other most vital necessities, yet allowed the people who used these to be seized (Diod. 1.79.5).

'The majority of lawgivers' here may have included Draco at Athens, whose laws allowed the sale into slavery of persons as security for debt, before Solon abolished this custom. ${ }^{29}$ If a ban on securing loans on military equipment was once in force at Athens, it had evidently lapsed by the early fourth century, since we hear of men forced by poverty to pawn their cuirasses and shields (Aristoph. Wealth 451). ${ }^{30}$

An important clue to the date at which abandoning one's arms and armour became an offence lies in its appearance in the law of slander. This law must go back to Solon, because the original version imposed a fine of only 5 drachmas, a tiny sum which makes sense only in an early sixth-century context, before the widespread adoption of coinage reduced the value of silver; in the fourth century, the fine was $500 \mathrm{dr} .{ }^{31}$ If the accusation of abandoning arms

Lys. 10.1: an eisangelia accuses Theomnestus of having thrown away ta hopla (in 10.12, the accusation is 'flinging away his shield', but this is a distortion in order to claim that Theomnestus had countersued despite the charge differing from the wording of the law); 10.9 quotes verbatim from the law, but here 'throw away' has no object (in 10.12, the object is 'shield' but this is a paraphrase, not a quotation); 10.23, 25 twice describe the legal case as between one who 'saved' and one who threw away ta hopla. At 10.212, descriptions of the action in battle refer specifically to the shield. Schwarz 2009, 26-7, argues that hoplon must have meant 'shield' in the law, but overlooks the use of the plural: ta hopla must refer to the rest of his equipment as well. Plato Laws $943 \mathrm{bc}$ specifically refers to a single individual throwing away plural hopla, as Saunders 1991, 324 n. 3, points out. I would suggest, therefore, that the references to the shield rather than ta hopla in Aeschines (1.29) and in Andocides' list imply that there are paraphrases, not quotations of the legal formula.

Note also the anecdote that Epaminondas, dying on the battlefield, asked first 'Is my shield safe?' and only then asked whether his army had won the battle (Diod. Sic. 15.87.6; Schwarz 2009, 153).

Since these sources criticised the laws in question, they are likely to be referring to genuine archaic laws; later or invented laws are typically attributed to early lawgivers as models of 'good' laws.

A scholion on the passage (repeated in Suda s.v. enechuron, e1291) suggests that it means poverty forced people to break the law, but that seems strained. The comment does, however, confirm that a ban on pawning armour once existed: 'Amongst prohibited things, it seems, is to deposit arms [ta hopla] as pledges. So he is saying about Penia [Poverty] that by her own force she compels [people] to break the laws which decreed not depositing arms as pledges' (trsl. D. Whitehead, Suda Online). Lipsius 1905, 456 n. 13 was wrong to reject this.

31 Solon, Laws fr. 32a R (Plut. Solon 21.1); 32b (Lys. 10.12); 33b (Lex. Cantab. 671.7). 
and armour was the subject of early sixth-century legislation, then the act itself must surely also have been made liable to legal punishment at this time.

If so, this legislation against the surrender of military equipment was a notable innovation. The evidence of Archilochus and Alcaeus shows that down to c. $600 \mathrm{BC}$, abandoning one's shield was not yet generally regarded as a crime. Archilochus' assertion that he did not care that he had dropped his shield to save his life ( $f r .5$ West) could perhaps be dismissed as a deliberately scandalous claim, appropriate to the genre of iambic song, but the same cannot be said for the elegy in which Alcaeus asked his friend Melanippus to tell people back home in Mytilene: 'Alcaeus is safe, but [his armour] men from Attica hung up in Athena's temple' ( $f r$. 438a L-P). Neither the genre, the rest of this poet's oeuvre, or the sentiment of the verses suggest any sort of mockery or defiance of convention, let alone a confession to a crime. What exactly the Athenians dedicated in Athena's temple at Sigeum is obscured by a serious corruption of the verse, but all three surviving ancient paraphrases of the text say that Alcaeus threw away 'his equipment' (ta hopla) in the plural, as in the Athenian law. ${ }^{32}$ An early sixthcentury ban on discarding military equipment was thus something quite new.

This explains what would otherwise have been a puzzle: what was the point of a separate law on abandoning military equipment, with a corollary in the law of slander, given that this was the ultimate act of cowardice and thus clearly a form of deilia covered by the law on astrateia? I suggest that, while the astrateia law introduced a new procedure for existing offences, the present law and the law on slander were substantive rather than procedural: they formally defined as illegal actions which had previously been merely shameful. ${ }^{33}$

Completing the legal provisions attested in classical Athens are further procedural laws which reinforced the punishment of loss of citizen rights. Persons convicted of military offences who were caught illegally entering the agora or attending sacrifices could be 'bound' and brought before the Heliaea court to suffer further punishment. ${ }^{34}$ A speaker in assembly who had avoided the draft or thrown away his shield (or maltreated his parents, prostituted himself, or wasted his inheritance) but had not been prosecuted, or had got away with ignoring the verdict, could be denounced on the spot and prevented from addressing the people. ${ }^{35}$ Aeschines' attribution of this and related laws to 'Solon, the ancient lawgiver, and Draco and the lawgivers of those days' (1.6) may not inspire confidence, but on the other hand the provisions of the law are neatly complementary to those of the astrateia and slander laws and may have been enacted at the same time, as part of systematic legislation on a citizen's military and other duties. ${ }^{36}$

See Hdt. 5.95; Strabo 13.1.38; Plut. Mor. 858b. A plausible emendation of the text includes a reference to entea, 'military equipment' (plural). The abandoned shield in Anacreon $f r .381 \mathrm{~b}$ has no context, so need not have been dropped by the poet('s persona). Schwartz 2009, 147-50 may be right that Archilochus was out to shock (contra Schwertfeger 1982; Van Wees 2004, 172) but his notion that Alcaeus tried to limit the damage to his reputation by composing a song about his own cowardice would make the poem the worst back-fire in the history of reputation management.

33 Van Wees 2004, 172, 174, argued that Archilochus' and Alcaeus' 'shameless' dropping of shields reflected the fluidity of the archaic phalanx, and that it was the emergence of the more rigid classical phalanx which led to the criminalization of shield-dropping. In view of Plato's explanation that the offence only occurred when an army had already been defeated, I would now suggest instead that its criminalization reflected an increase in the symbolic value of ta hopla without also implying a change in the nature of archaic hoplite combat, which on other grounds I still regard as quite fluid.

34 Dem. 24.103; a trial before the Heliaea is attested only by a law inserted into the text (24.105), but is a logical consequence of 'binding', since imprisonment was not a punishment in its own right.

35 See esp. Aeschin. 1 (esp. 28-30); Lys. 10; with Fisher 2001, 157-9; Lipsius 1905, $278-82$.

36 In Aeschines' version, the law has a subject heading, dokimasia rhêtorōn, which is unlikely to have been a feature of the archaic law, but may simply have been added when the laws were re-inscribed in 403 
So much for military laws attested in classical Athens which may go back to the archaic period and to Solon. In addition, we have evidence for archaic laws which were no longer valid in the classical period, regulating the provision of arms and armour, horses and ships by citizens. A duty to provide arms and armour is attested in the oldest surviving inscribed public Athenian decree, dated to c. 500 BC. This decree sets out the obligations of Athenian settlers on Salamis, who must 'pay taxes and perform militar[y service]' and '[themselves] p[rovi]de military equipment [worth t]hir[t]y dr[achmas]', to be inspected by the local magistrate $\left(I G \mathrm{I}^{3}\right.$ 1.3, 8-12) ${ }^{37}$ Likely restorations of the damaged text suggest that these duties also applied at Athens. ${ }^{38}$ In view of the date, one could take this obligation as an innovation introduced by Cleisthenes' reforms in $508 \mathrm{BC}$, but in that case it would be surprising that not a single classical text refers to a legally prescribed minimum value of the military equipment a citizen was required to own. In the light of this silence and of Aristotle's observation (cited above) that a legal obligation to acquire arms and armour was typical of oligarchies but not democracies, it seems more likely that our inscription represents pre-democratic practice, still in use in Cleisthenes' day, but no longer enforced by the late fifth century.

The system of property classes which Solon is said to have used to allocate a range of political rights on the basis of wealth is likely also to have served to allocate a range of military obligations, as we shall see. By making hoplite service obligatory for the three highest property classes, this system made ownership of arms and armour compulsory for men at this economic level, and it would have been only a small step further to define an acceptable minimum for military equipment. The military role of these property classes is no longer attested after the Peloponnesian War (pp. 000-00, below).

Already under Solon, Athens had a body of officials, the naukraroi, charged with mobilising military resources. The naukraroi and their districts, the naukrariai, featured in several laws which the sources reliably attribute to Solon but were obsolete in the classical period. Later lexica mention these officials' military responsibilities:

A naukraria was for some time the twelfth part of a tribe, and there were twelve naukraroi, four in each 'third'. These men voted on the war tax-levies (eisphorai) in the demes and the expenditures from them. Each naukraria provided two horses and one ship, after which it was probably named (Pollux 8.108). ${ }^{39}$

Since these military roles are not mentioned by earlier sources, many scholars have rejected the lexical evidence as a product of unreliable later speculation, but naukraros and naukraria can only mean 'ship's captain' and 'captaincy' so these institutions must have had a naval function. The omission of this naval role from classical accounts such as the Aristotelian Athenaion Politeia reflects, I have argued elsewhere, an anti-democratic view which denied the 'naval mob' any place in Athens before the Persian Wars. Institutional arrangements for mobilizing warships are well-attested in medieval European kingdoms with only a modest level of state-formation and there is nothing inherently implausible in their existence in archaic Athens. Since there were four 'tribes' in Solon's day, the 'captains' between them provided 48 ships in war, compelled 96 citizens to serve as cavalry, and raised war taxes. ${ }^{40}$

(like the heading 'first axon' in Draco's homicide law).

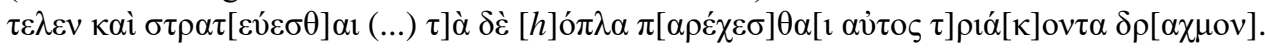

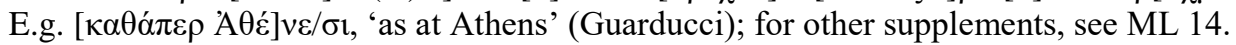

Also Lex. Seg. 1.283.20: naukraroi are 'those who provided the ships, acted as captains and were subordinate to the polemarch'; since the polemarch had lost his military role by the classical period, this statement is based on at least some knowledge of archaic Athenian institutions.

40 For a full discussion of the evidence, see Van Wees 2013b, 44-61; cf. Figueira 2011, who also treats the naukrariai as a genuine archaic military institution, contra e.g. Gabrielsen 1985 (cf. 1994, 19-24); Frost 2005, 106-7, 152-53, 175-90; Schubert 2008, 39-48; Pritchard 2010, 8-15. Duplouy, this volume, p. 000- 
A further military role is implied by an oral tradition which credited 'the chiefs of the naukraroi' with leading the Athenian troops in opposing an attempted coup d'état by Cylon, a generation before Solon (Hdt. 5.71). The 'captains' were evidently responsible for mobilising infantry as well as cavalry and ships, and could in principle have had the formal authority to enforce an obligation to serve and to provide arms and armour of a certain minimum value.

Finally, the earliest surviving Greek poetry hints at compulsory military service even before Solon and the introduction of written law. There is admittedly no sign of this in the martial exhortations of Callinus or Tyrtaeus, which allude only to the soldier's fear of shame and hope of fame, but one would not expect to raise morale by threatening punishment. ${ }^{41}$ Compulsory service does, however, feature in Homer's Iliad and Odyssey.

While the various leaders among the Greeks follow Agamemnon voluntarily, as a favour, the men who follow these leaders in turn include Euchenor of Corinth who went to Troy 'to avoid the harsh punishment of the Greeks' (Il. 13.663-70) and the son of Polyctor who drew lots with his six brothers to decide which of them would go to Troy with Achilles (24.396400). Homer's word for 'punishment', thōe, is a normal legal term for 'fine', and whether or not it already had this meaning in epic, it is clearly a sanction communally imposed by 'the Greeks' for failure to serve. The drawing of lots amongst brothers implies that the family was under an obligation to send one, and only one, man to Troy; whether the obligation was to Achilles personally, to king Peleus, or to the community of the Myrmidons, we cannot tell. In the Cretan stories in Odyssey, we hear both of a man embroiled in a violent feud because he refused to go to Troy as a follower of the king (Od.13.256-66) and of a man reluctant to lead troops to Troy but compelled by the community to do so: 'there was no way at all to refuse, for harsh was the voice of the people' (14.235-9). Even on the side of the Trojans, threats of coercion reinforce the powerful motive of fighting in self-defence: Hector threatens to kill a man for shirking the fight or encouraging others to hang back (Il. 12.248-50). He also says that he 'will not allow' any man to leave the army and that

a Trojan who is excessively concerned about his property must collect it and give it to the

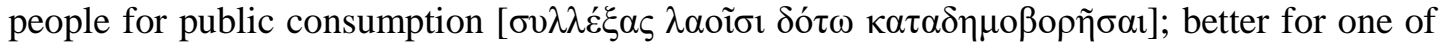
them than for the Greeks to enjoy it (18.296-302).

This rather obscurely worded passage only makes sense as a threat: a man who deserts to look after his property rather than risk his life in war will be punished with public confiscation of his wealth, which after victory will be enjoyed by another owner.

In sum, military service was not entirely a matter of voluntary participation even in the heroic world of Homer: informal but powerful forms of coercion, including the death penalty for cowardice and confiscation of property for desertion, are attested. Given the importance of warfare, these forms of coercion are likely to have been among the first to be formalized when laws began to be written down from c. $650 \mathrm{BC}$ onwards. Accordingly, one would expect the laws of Solon, too, to have addressed such matters, and indeed we find that the law which

00, and 2014, 649, notes a parallel for obligatory provision of horses in a law of Cyme: 'each citizen was under compulsion to keep a horse' (Arist. fr. 611.39 Rose). abroad with family and parents might have been formally exiled (Cairns 1993, 162) or in voluntarily exile to escape a worse punishment (Ducat 2006, 10), but seems to me more likely to be refugee after the destruction of his city (Van Wees 2004, 149 n. 56; 2011, 95-6). One may compare the emphasis on voluntary sacrifice and the absence of any mention of the draft in classical Athenian funeral orations for the war dead, who had mainly been conscripted, as noted by Christ 2006, 63-4. 
made it a punishable slander to accuse a man of having abandoned his arms and armour must go back to Solon, as must the law which made it a crime to abandon one's equipment. We cannot independently date the various procedural military laws, but they are attributed to Solon, they prescribe a procedure that features all the elements associated with Solonian legislation, and they must be relatively early since they were out-of-date by the fourth century. Yet other laws which clearly are of Solonian date testify to the existence of authorities, the 'captains', in charge of mobilising troops, horses, ships and money for war. All this amounts to a strong case for the imposition of legal military obligations on citizens in or by $594 \mathrm{BC}$. We may conclude that in Solon's time, if not before, citizen duties to provide arms and armour, horses and ships were formalized; abandoning one's equipment was criminalized; officers and the assembled militia were given formal legal power to punish men who fell short in any of their military obligations, and supplementary laws deterred false accusations while also imposing additional penalties on those who flouted the verdict of the soldiers.

\section{Universal military duties: waging war 'with the whole people' (pandēmei)}

On whom were these various military obligations imposed? The prosecutor of Alcibiades raised this very question and answered with two further rhetorical questions (Lys. 14.6):

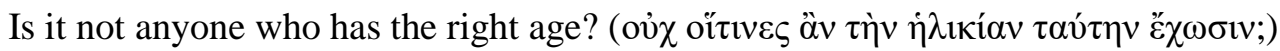

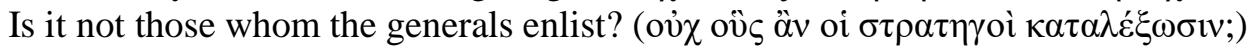

These two categories, I would argue, do not combine to mean 'anyone of the right age who is drafted by the generals' - which would be redundant since it surely went without saying that the generals enlisted only men of military age - but refer to two types of levy. In one, 'anyone of the right age' was obliged to serve; in the other, only those hand-picked by the generals. Modern scholars have had much to say about the second type, selective conscription by 'listing', which supposedly prevailed in fifth-century Athens and was replaced by mobilization 'by age group' in the fourth century, but they have virtually ignored the first type, the general levy of 'the entire people' (pandēmei) or 'the whole army' (panstratiai), ${ }^{42}$ which is nevertheless well-attested in archaic and classical Greece. ${ }^{43} \mathrm{We}$ shall see that the general levy was a major feature of citizens' military lives, which imposed obligations on all men but only lightly enforced these, while selective conscription imposed stricter obligations, but on far fewer citizens than is usually envisaged.

An Athenian general levy invaded Megara in 431 BC (Thuc. 2.31.1), the largest Athenian army ever assembled, including 'no fewer than 10,000' citizen hoplites, 'no fewer than 3,000' metic hoplites, 'besides a large crowd of light-armed' (psiloi, 31.2). Comparison with the figures for total Athenian hoplite manpower in that year (2.13.6-7) shows that this levy did not include 'the oldest and youngest' who were stationed in forts and on the city walls, and so

In a military context, the two terms are interchangeable, as is clear from e.g. Thuc. 2.31; in a non-military context, pandēmei can include women and children: e.g. Thuc. 1.90.3, 126.6; 3.3.3; 5.82.6.

Christ 2001, an exhaustively detailed study of mobilization, finds room for only two sentences on the subject: 'When military objectives warranted it, ... hoplites ... or all able-bodied men ... could be called upon to take the field en masse' (408-9); 'Mass mobilizations, in fact, are the exception rather than the rule in Athenian military history; normally the generals needed only a fraction of the available hoplites...' (411; cf. 2006, 53). See also Jones 1957, 178. Hansen 1985, 83-9; Hamel 1998b, 24-8, do not consider general levies at all. 
presumably included only those over 20 and up to about 40 years of age. ${ }^{44}$ These panstratiai incursions continued twice a year, albeit with shrinking numbers on account of manpower losses to the plague, until $424 \mathrm{BC}$ (4.66.1).

In that year, an Athenian general levy crossed the city's other border to invade the territory of Tanagra in Boeotia, as it had done at least twice before, in 457 (Thuc. 1.107.5) and 426 BC (3.91.4): 'Hippocrates mobilized the Athenians pandemei - the Athenians themselves and the metics and any foreigners who were present' (4.90.1). This again included 'lightarmed', who were explicitly not specialists but simply 'many non-hoplites (aoploi) who followed since there had been a general levy of the available foreigners and the citizens'. These light-armed were thus ordinary poorer citizens, and their number is said to have been 'many times' (pollaplasioi) that of the Boeotians (94.1), who had 'more than 10,000 lightarmed' (93.3). 'Many times' ought to imply more than double the number, which could only be true if light-armed of all ages, not just the 20-40 year-olds, joined the levy; alternatively, Thucydides exaggerated and there were at most 15,000 Athenian light-armed. ${ }^{45}$ They would still have outnumbered the hoplites: Thucydides implies that there were at least 7,000 Athenian hoplites $(93.3,94.1)$ and there can have been no more than $10,000 .{ }^{46}$ 'The majority of the light-armed' had left the area before the Boeotians counterattacked, and only 'a few' were left $(90.4,94.1)$, but nevertheless 'a large number of light-armed (psiloi) and baggagecarriers (skeuophoroi)' died in battle (101.2). This last phrase confirms again that the lightarmed were not baggage-carriers, i.e. the hoplites' personal attendants (usually slaves), but soldiers in their own right. ${ }^{47}$ The same was surely true of the 'crowd' of light-armed that joined the twice-yearly invasions of Megara. ${ }^{48}$

While it is of course true that Athens conducted many more campaigns during the Peloponnesian War that did not involve general levies, this is hardly surprising given the nature of the conflict as a war for naval hegemony, and we should rather stress that all Athens' acts of aggression against its immediate neighbours during this war were undertaken by general levies. If Athens had not adopted the 'Periclean strategy' of offering no full-scale opposition to Peloponnesian invasions of Attica, we would no doubt have seen general levies mobilized in defensive action as well. Our evidence for fourth-century wars is less detailed and likely to understate how common general levies were: it is only due to a chance allusion in Lysias (3.45) that we know the Athenian contingent in the battle of Coroneia in 394 BC to have been a general levy - none of our narrative accounts say so. This general levy did not merely make a quick raid over the border but marched right across Boeotia. Even more

Hansen 1981, 19-24; 1988, 23-5 assumed an upper age limit of 50 and noted that this was demographically incompatible with Thucydides' numbers for field troops and home guards; Van Wees 2004, 241-2 suggests that the simple solution is to assume instead an upper age of 40 .

In $431 \mathrm{BC}$, citizens and metics together provided 30,000 hoplites and cavalry (Thuc. 2.13.6-7); the citizen population at the time has been estimated at 60,000 (Hansen 1988, 14-28) to which we should add c. 10,000 metics, i.e. potentially 40,000 light-armed of all ages, which after deduction of losses to the plague leaves some 27,000; the 20-39 year-olds would constitute c. $60 \%$, i.e 15,000.

Given a field army, incl. metics, of up to 16,000 in 431 BC (Thuc. 2.13.6) and losses of about one-third to the plague plus casualties of war, Athens would have had no more than 10,000 hoplites left.

47 See esp. Welwei 1974, 57-65. Since the purpose of the levy was to fortify a position in Boeotian territory, it has been suggested that the numerous light-armed were included only to help construct fortifications, and would not normally be part of a general levy in such numbers (Gomme ad loc; cf. the pandemei wallbuilding at Athens in 479 (Thuc. 1.90.3), at Argos in 417 (Thuc. 5.82.6) and by Athenians at Corinth in the late 390s (Xen. Hell. 4.4.18). However, Thucydides' explanation for their presence is simply 'since there had been a general levy' (hate panstratias genomenes), which implies that their large-scale mobilisation was routine, as Aeneas Tacticus also assumed: see below.

48 Cf. Thuc. 1.106.2 for Athenian psiloi fighting in Megarian territory, c. 459 BC, when even the oldest and youngest hoplites are deployed in the absence of the bulk of the field army. 
remarkably, an Athenian general levy came to the aid of Sparta in 369 BC: in the morning the assembly decided on a pandēmei expedition led by Iphicrates and by dinner time ' 12,000 young men' had gathered at the Academy; 'they say many came out before Iphicrates himself did'. This force marched all the way to Corinth, and from here made a series of incursions into Arcadia (Xen. Hell. 6.5.49, 51-2; Diod. 15.63.2).

Athenian fleets could be mobilized by general levy, too. Near the start of the Peloponnesian War, fire signals warned the Athenians of a Spartan night attack on Salamis, so that at dawn 'the whole community' came running down to the harbour, embarked chaotically, and crossed over to the island (Thuc. 2.94.2); a very similar incident occurred in 411 (Thuc. 8.94.3). The ships that fought the Persians in 480 were manned 'by the whole community' (pandemei, Hdt. 7.144.3; Thuc. 1.73.4), but on this occasion there was time to prepare and a more organized procedure was adopted, according to the Decree of Themistocles (ML 23), as inscribed in the third century BC. The generals divided up the citizens and the metics into 200 crews, one for each ship. There were only 100 oarsmen per ship, rather than the normal 170, so it is clear that the generals were not selecting crews but co-ordinating the allocation of as much manpower as Athens could raise at the time. At least part of the shortfall was surely made up by slaves brought along by citizen oarsmen. ${ }^{49}$ This certainly happened at Arginousai in 406, when the Athenians embarked 'all those who were of military age, both slaves and free men'. This general mobilisation was slow - it took 30 days (Xen. Hell. 1.6.24) - and produced a low-quality fleet, which was forced to adopt a unique double-line formation to prevent loss of formation (1.6.29-32). ${ }^{50}$

At Salamis and Arginousae, total available citizen manpower was not enough to fill the ships and mobilization was genuinely universal, but most fleets were not quite so large and did not quite need all available manpower, so that a degree of selection took place even when the levy was on such a large scale that it was as good as 'general'. We hear that 'the Athenians themselves' crewed 100 ships in 428 BC (Thuc. 3.16.1), or 83 ships in 394 (Xen. Hell. 5.4.61; Diod. 15.34.3-35.2), and these numbers would have required virtually all citizens up to the age of 40 , to be involved, even if the term 'general levy' is not used. ${ }^{51}$ Both on land and at sea, Athenian general levies typically mobilized all or almost all free men, citizens and resident foreigners, regardless of social status or military equipment, and often large numbers of slaves as well. The only restriction seems to have been one of age, judging by Thucydides' comment that 'the oldest and the youngest' stayed at home to guard the walls and forts, leaving the mass invasions of Megara to men up to the age of 40.

Athens was not unusual in this respect. The Spartans raised a general levy, led by one of the kings, five times during the Peloponnesian War. Twice, the levy barely went beyond the borders of Laconia (Thuc. 5.33.1, 54.1), but on two occasions, both in $418 \mathrm{BC}$, 'the citizens themselves and the helots marched out pandemei' $(5.57 .1,64.1)$ to invade Argos and

Hunt 1998, 41 draws attention to Hdt. 8.142, where a Spartan refers to Athenian 'slaves (oiketai) useless for warfare', presumably as opposed to those slaves who were useful and served in the fleet.

Cf. Plato Men. 243c; Diod. 13.97.1. Hunt 1998, 87-95 argues convincingly that the mobilisation of slaves on this occasion was unexceptional, although their reward - enfranchisement and citizenship - was unusual, one of several such schemes in the last years of the war. It was surely the exceptionally high proportion of citizens in this fleet which caused the outcry in Athens against the generals' failure to rescue the crews of 25 lost ships $(1.6 .34 ; 1.7)$.

Assuming 30,000 adult male citizens in 394, the 20-39 year-olds would have numbered about 18,000, when 83 ships required 16,600 men. The population was larger in 428, but at that time Athens also had citizens serving on another 170 ships (100 guarding Attica, Salamis and Euboea, 3.17.1; 40 on Lesbos, 3.3; 30 in Western Greece, 3.7), so there will barely have been enough to provide the 20,000 men required for the additional 100 triremes. 
Mantineia respectively, and in $404 \mathrm{BC}$ a general levy marched all the way to Athens, laid siege to the city, and forced the Athenians to surrender (Xen. Hell. 2.2.7). An age limit on citizen participation is indicated by the fact that on the expedition against Mantineia one-sixth, 'the oldest and youngest', turned back at the border and went home to defend Sparta (5.64.23 ). The mobilization of the helots is remarkable. Two units of helots equipped as hoplites are mentioned in the Mantinea campaign, ${ }^{52}$ but Thucydides can hardly have been referring to these when he spoke of 'a general levy of helots'. ${ }^{53} \mathrm{He}$ surely implied that a great number of helots took the field, presumably as light-armed rather than as hoplites, since he made no further reference to them in his detailed discussion of hoplite numbers. ${ }^{54}$

An exact parallel occurs in Herodotus' account of the Spartan levy for Plataea in 479 BC. This involved the mobilization of 35,000 light-armed helots, 'every single one equipped for war' $(9.29 .1$; cf. 10.1; 28.2), as well as 5,000 Spartiates. A battlefield grave for the fallen helots proved their presence (9.85). Herodotus implies a contrast with the 'select' perioikoi (logades) mobilised at the same time (9.11.3), so this force of Spartiates and helots is likely to have been a general levy, as indeed the huge numbers suggest. ${ }^{55}$ It seems likely, therefore, that Spartan general levies normally included large numbers of helots serving as light-armed infantry, just as Athenian mass mobilizations included light-armed citizens and slaves.

Thucydides further describes in some detail the repeated mobilization of a general levy of Syracusans in the face of the Athenian invasion of 415 BC $(6.64 .1,3 ; 65.1 ; 91.2)$. The inferior quality of 'men who defend themselves with the entire community' compared to 'selected' troops like the Athenian force is deemed self-evident (6.68.2), and it may have been their lack of confidence as much as their larger number which made the Syracusans adopt a formation twice as deep as that of the enemy (67.2). As in Athens and Sparta, the general levy included light-armed - stone-throwers, slingers, archers - who engaged their Athenian counterparts 'in the usual manner' before the hoplites advanced (6.69.2). The general levies of other Greek states are not described in any detail, but they are mentioned often, taking the field not only in defensive action against invaders, ${ }^{56}$ but also to attack neighbours ${ }^{57}$ and to help distant allies. ${ }^{58}$ In one remarkable instance, a general levy from all cities of Achaea crossed the Corinthian Gulf to invade Acarnania (Xen. Hell. 4.6.3). The defeat of an Ambraciot general levy illustrates once more that such forces are of a different order of magnitude from levies by 'listing': Thucydides refused to give the huge number of casualties since no one would believe him $(3.105 .4,110.1,113)$. The Corinthian general levy again left behind 'the older men' to defend the city, though they might come out in an emergency (Thuc. 4.42.3; 4.44.4).

'Brasideians', incl. 700 helots (4.80.5), and an unspecified number of emancipated helots (5.67.1).

Contra Gomme, Andrewes and Dover 1970, ad loc. Hunt 1998, 60-1, summarizes other attempts to explain away the helots and suggests a parallel with the light-armed helots at Plataea, below (1998, 33-9). The reason why Thucydides mentioned the helots in 418 but not in connection with the two earlier general levies may be that he was concerned to stress the scale of the army of 418 , which he described as 'the finest Greek army up to that point' (5.60.3).

55 The Spartans are said to have planned a pandēmei levy in 480 (Hdt. 7.206) before events at Thermopylae overtook them, and the situation was at least as critical in 479. Herodotus' figure of 5,000 Spartiates is well below the total figure of 8,000 Spartiates of military age which he mentions elsewhere (7.234.2), but I would argue that the latter figure reflects the tradition that the original number of Spartiate citizens was 9,000, and that by $479 \mathrm{BC}$ the actual number had fallen to little more than 5,000: Van Wees, forthcoming. E.g. Hdt. 7.203 (Locrians at Thermopylai); Thuc. 3.5.2 (Mytilene); 5.57.2 (Phleious); 8.55.3, 61.3 (Chios).

$57 \quad$ E.g. Thuc. 2.5.1 (Thebes v. Plataea); 3.7.3 and 94.1 (Acarnanians v. Oiniadai, Leukas), 3.95.3 (Locrians v. Aetolians); 4.25.7 (Messana v. Naxos); 5.75 .4 (Epidaurus v. Argos); 6.7.2 (Argos v. Orneai); Xen. Hell. 1.3.10 (Chersonesitans v. Selymbria, Byzantium); 5.4.42 (Thebes v. Thespiai); 7.2.4 (Argos v. Phleious). Mytilene).
} 
The age limitation on general levies attested in Athens, Sparta and Corinth means that such mass mobilizations, reported down to $369 \mathrm{BC}$ in Athens, were fundamentally no different from the supposedly new system of levy 'by age class', attested at Athens from 366 $\mathrm{BC}$ onwards. Aeschines says that his first experience of military service occurred in that year, when he went on 'a campaign called "by the sections" (en tois meresi)', along with his 'contemporaries' (hēlikiōtōn), and that he subsequently also went on 'the other successive expeditions by eponyms and sections' (2.168), as well as further campaigns, including one where he served among the 'picked troops' (epilektoi, 2.169). 'The eponyms' were 42 heroes who gave their names to 42 year-groups of citizens aged 18-59, and men could be mobilized by sets of year-group, from eponym A to eponym B ([Arist.] Ath. Pol. 53.4, 7), so Aeschines must mean that in his day a set of year-groups was called 'a section', and that mobilization of all men within a certain age class could be variously called 'by sections' and 'by eponyms'. 59 Plato similarly distinguished between service 'in a section' and service by selective conscription (Laws 943a3-4). Several mobilizations by age are attested: in 352, the Athenian planned but failed to send out 40 ships manned with citizens up to the age of 45 (Dem. 3.4); in 347, they manned 50 ships with men up to the age of 40 (Aeschin. 2.133); and in 322, they levied men up to the age of 40 for the army (Diod. 18.10.2).

Scholars have assumed that this was a wholly new system of mobilization, which replaced selective conscription by 'listing' not long before $366 \mathrm{BC}$, and it has been suggested that much smaller expeditionary forces were mobilized in the same way, by calling up only a very few year-groups ${ }^{60}$ In fact, for smaller forces selective conscription by 'listing' continued to operate until at least $348 \mathrm{BC},{ }^{61}$ and we have no evidence for mobilizations of less than 20 or 25 year-groups at a time. Such large, non-selective levies 'by sections' were in effect the same as the earlier 'general levies', typically restricted to the same age range. Indeed, the system of organizing citizens into year-groups with eponymous heroes may go back to the Peloponnesian War, or earlier: it is not mentioned by Thucydides, but we are told that Philochorus' account of fifth-century Athens described it 'in detail', which suggests that he believed it to have been in place already. ${ }^{62}$ Whether or not this is true, the mid-fourth-century system in essence continued the earlier general levy.

The classical general levy in turn continued archaic practice. As noted above, the earliest known event in Athenian history, the attempted coup d'état by Cylon in the 630s, involved a pandèmei mobilization 'from the countryside' (Thuc. 1.126.7) which laid siege to the Acropolis for a few days, before the troops started leaving and their commanders - the archons according to Thucydides, the 'chiefs of the naukraroi' according to Herodotus (5.71) - led the remaining soldiers in a massacre of Cylon's supporters. As Thucydides envisages it, this was clearly not some spontaneous gathering but a formal mobilization, led by the chief magistrates. The detail that many men left before the end may serve to exculpate the majority of citizens from the 'curse' attached to the ensuing massacre, but it is also a plausible story

So convincingly Christ 2001, 409-15, 2006, 52; contra Andrewes 1981 and Van Wees 2004, 103-4. One of Aeschines' campaigns was to Mantineia in 362, where the Athenians sent 6,000 hoplites (Diod. 15.84.2), presumably a general levy limited to rather few age groups (20-35?). Xen. Poroi 3.7 says that much money was spent on the army in 366 and 362, implying that these levies were paid.

60 Contra Christ 2001, 411. The general idea that age-class mobilization replaced selective conscription was wrongly adopted also by e.g. Van Wees 2004, 103-4; Hamel 1998b, 26-8.

61 Contra Christ 2001, 415 (and with Hansen 1985, 110 n. 248), Dem. 39.8 of 348 BC is clear evidence for the continued existence of selective conscription: the argument relies on a system in which soldiers are individually conscripted by name, not by year-group. Plato's Laws (as cited above), of about the same date, also recognizes selective conscription alongside mobilization 'by section'.

62 Philochorus FGrHist 328 F38; the discussion featured in his Book 3, which covered the fifth-century to 404 BC. Christ 2001, 412 n. 54; Harding 2008, 121 assume that it was a digression. 
about a general levy, which was harder to control and included many poorer men who could not afford a long absence from work and were in a hurry to go home.

Another general levy took place in 546 BC, when Peisistratus and his allies marched from Marathon towards Athens and 'the Athenians from the city' responded with a panstratiai mobilization, defeated by a surprise attack on their camp at Pallene (Hdt. 1.62.3). This levy took a long time to materialize, and some Athenians took Peisistratus' side, but that does not mean it was more voluntary or less formal than any later general levy. Much has been made of Athenian resistance against Isagoras and his Spartan allies in 508 BC, supposedly a uniquely spontaneous democratic uprising, but the precedents of opposition to Cylon and Peisistratus suggest that this, too, was simply a general levy raised by the relevant magistrates to resist an attempted coup with external support. ${ }^{63}$ Whether the Athenian forces that occupied parts of Boeotia in 519 and Chalcis in 506 were general levies we are not told, but given that they must have been large armies, it does seem likely. ${ }^{64}$

At Marathon in 490 BC, the Plataeans came to Athens' aid pandèmei (Hdt. 6.108.1), and one would imagine that the Athenians themselves mobilized en masse, too. Herodotus does not say so, but neither does he say that only the hoplites or a more select body marched out: he simply speaks of 'the Athenians' throughout (6.103-117). ${ }^{65}$ The number of 9,000 Athenian hoplites at Marathon given by later sources, ${ }^{66}$ like the 8,000 hoplites at Plataea in $479 \mathrm{BC}$ (Hdt. 9.28.6), must have amounted to a general levy of all 20-40 year-old hoplites at least, given that two generations later a larger Athens could still muster only 13,000 men in that age group. As for non-hoplites, later tradition said that the levy included even 'unfit men' and slaves (Paus. 10.20.2); these slaves were said to have been freed before battle, and slave casualties were given a tomb near the battlefield (Paus. 1.32.5; 7.15.7). If slaves fought, nonhoplite citizens surely also fought at Marathon, ${ }^{67}$ as irregular light-armed, just as they did at Plataea, where light-armed were as numerous as hoplites (Hdt. 9.29.2).

For most of the archaic period, Athenian fleets were not large enough to require a general mobilization, but with the introduction of the trireme in the late sixth century, manpower demands increased, and just before or after Marathon, when the navy reached 70 triremes, it would have taken almost all citizens aged 20-40 to man it. But Athens may have already relied on hired oarsmen, including non-citizens, rather than on compulsory mobilisation, and the first general naval mobilization may not have taken place until $480 \mathrm{BC}{ }^{68}$

Over a span of three centuries, we thus see general levies defending Athens, crossing the border into Boeotia, Megara and Corinth, and occasionally manning fleets to fight on the other side of the Aegean, often if not always including citizens of all classes as well as

63 See Van Wees 2008, 20-5; contra Ober 1993.

64 Hdt. 6.108.4-6 and 5.77, with discussion in Van Wees 2013b, 68.

65 It has often been inferred that Herodotus meant hoplites only because he claims that the Persians thought the Athenians were 'mad', 'since they saw that they were few, and that these men were driving themselves forward at a run, without having horse or arrows at their disposal' (6.112). Rather than an indirect authorial claim that the Athenians had no cavalry or light-armed at all, this is surely meant to represent a Persian impression of the majority of Greek troops charging towards them, who, whether hoplite or light-armed, lacked the two weapons on which the Persians most prided themselves: horse and bow (e.g. Hdt. 1.136). Athens may well have sent its few hundred cavalry and archers to Marathon, but Herodotus could very plausibly imagine that these would not have made much of an impact on what the charge looked like from a Persian perspective.

66 9,000: Paus. 10.20.2; Nepos, Milt. 5; Suda s.v. Hippias (1)/1 545. 10,000: Justin 2.9.

67 Unless Hunt 1998, 26-8, is right that arming slaves was less threatening than arming poor citizens.

68 Seventy triremes: Hdt. 6.92, 132, with discussion in Van Wees 2013b, 64-8. They would have required 14,000 men, when Athens may have had c. 18,000 20-40-year olds (see above, n. 51). 
resident foreigners and slaves, restricted only by age, with 40 or 45 as the upper limit. Spartan general levies marched even farther, and had a higher age limit, ${ }^{69}$ but otherwise the same pattern of age-limited mass mobilization occurred here and elsewhere in Greece.

The sheer scale of such mobilizations, the short time in which they often had to be arranged, and the participation of poor, light-armed citizens who so far as we know were not organized in units under commanders but formed a mere 'mob', must have made it hard to exercise control and to ensure that citizens met their obligation to take part.

This is best illustrated by the account of defensive mobilization in Aeneas Tacticus' How To Defend a City. When 'a message or fire signal' announces that an enemy has crossed the border, men gather to defend 'the part of the territory being damaged' (15.1). At this point, especially if the warning arrives suddenly or at night, the city is in chaos, and it is up to the generals to create a viable army from scratch. Their immediate task is to stop citizens from rushing out in small scattered groups 'to rescue their possessions from the countryside' (15.2; 16.2) and to ensure that the men are organized into improvised units: 'the generals must gather together those who turn up at the gates until a certain number has been reached, a full unit or two units, then organize them and give them a sensible leader', and only then let them march out, 'as much as possible in formation' (taxis, 15.3). A series of such ad hoc units are sent out in rapid succession, so that each 'section' (meros) is close to the others, and all can quickly join forces if necessary without having to 'come running from far away' (15.4). Signs are put up at forks in the road and wherever routes diverge, so that 'those who are left behind' will not get separated from the rest (15.6). The same kind of gradual, informal mobilisation features in a historical example cited by Aeneas: in 376/5 BC, the people of Abdera responded to an invasion by Triballians 'with all speed, strength and commitment' (15.9) and, undeterred by initial losses, "called out to one another to hurry to the rescue of those who had marched out, until the city was emptied of men' (15.10). ${ }^{70}$

The generals had to contend not only with citizens excessively eager to fight but also with men who were 'afraid to face danger' or 'completely unprepared' and thus unwilling or unable to march out (16.2). Accordingly, they needed not only to encourage the fearful but also to 'provide equipment for some' (tous de hoplizonta, 16.3), presumably by handing out arms and armour from a public store, perhaps an arsenal or more probably a temple, to those 'unprepared' men who turned up at the gates without their own kit.

Although the instructions so far concern the hoplite forces, they were not the only or even the first troops to march out. The generals must send ahead 'the available cavalry and lightarmed [kouphoi]' to reconnoitre and occupy heights, in order to protect the hoplites (15.5). When the time is right to attack the invaders, the general should use the cavalry to occupy in advance the enemy's lines of retreat, 'set ambushes with the picked troops [epilektoi] and show yourself to the enemy with the other light-armed', before finally leading forward the assembled hoplites 'in formation, not far behind the sections sent ahead' (16.7). The picked troops are here evidently envisaged as light-armed and must be either specially trained citizen units or mercenary troops; accordingly, 'the other light-armed' must be the citizens who could not afford to serve as hoplites. These poorer men thus led the way, but were if anything even less regularly organized than the hoplite units which followed. ${ }^{71}$

69

The 'oldest and youngest' sent home in 418 amounted to only one-sixth (Thuc. 5.64.3), i.e. 18-19 and 5559 year-olds; the Spartan army at Leuctra included men up to the age of 55 (Xen. Hell. 6.4.17). Date: Diodoros (15.36.1-4), who explicitly speaks of an initial 'pandēmei' mobilisation, but differs from
Aeneas in blaming the ultimate defeat of Abdera on treachery by Thracian allies rather than on excessive zeal and a lack of organization.

71 Contra Best 1969, 120-1; Whitehead 2001, 139, 141-2, who take the kouphoi to be specialist units. 
In Aeneas' general defensive levy, everything is improvised, and the same must be true of the times when the Athenians ran down to Peiraeus to launched their ships in a panic, or when 12,000 men marched out in aid of Sparta within hours of the decision to mobilize en masse. Even in less hurried general levies the process often seems to have been highly informal. The Syracusan levy in 415 BC was so loosely organized that at the start of battle 'some men' who had gone back to town were forced to run out again and belatedly take a place in the army wherever they could (69.1). The 'disorganised anarchy of the masses', as well as a lack of experience and training, was subsequently blamed for defeat (6.72.3-4; cf. 6.70.1; 7.3.3). When the Athenian general levy marched to Coronea in 394, a certain Simon did not join them until the battle was over, and proceeded to beat up his regimental commander (Lys. 3.45). The group of demesmen who reach the battlefield only when combat is already in progress in Theophrastus' Characters (27 [25] 3-4) are best understood as late arrivals in a general levy, too. And in a naval mobilization of $362 \mathrm{BC}$ which was probably also a general levy, many demesmen never reported to their ships at all; rather than chase after them, the captain decided to hire professional rowers instead ([Dem.] 50.7). ${ }^{72}$

At the other extreme, it may not be a coincidence that some stories about citizens putting up an impressive display also occur in the relatively informal setting of a general levy. It was in the mass naval mobilization of $480 \mathrm{BC}$ that Cimon 'and friends' made a show of volunteering to serve as humble marines despite being high-status horsemen by walking in procession up the Acropolis and dedicating their spurs (Plut. Cim. 5.2), while Cleinias son of Alcibiades turned up with a private trireme and crew (Hdt. 8.17). At Tanagra in 457, Cimon is said to have tried to join the levy despite being in exile, and when he was barred from doing so arranged for 'his friends' to form a unit of 100 and carry his panoply in combat, fighting to the death to prove their and his loyalty to the city (Plut. Cim. 17.3-5).

Despite the often chaotic nature of mass mobilizations, taking part in a general levy in classical Athens was in principle compulsory, not merely voluntary. One Xenocleides was convicted of astrateia for failing to join the levy of 369 BC; he was hardly a typical case, since he had publicly spoken out against the expedition and so made himself vulnerable to prosecution, but the fact remains that even after a barely controlled mass mobilization an absentee was in principle liable to be prosecuted for failure to serve ([Dem.] 59.27). In the probable general naval levy of $362 \mathrm{BC}$, the assembly ordered 'the Councillors and demarchs to make lists [katalogoi] of demesmen and deliver naval personnel' ([Dem.] 50.6), rather than rely on volunteers, and the Decree of Themistocles envisages a similar compulsory mobilization for the general naval levy of $480 \mathrm{BC}$, not only for citizens but also for metics (ML 23.27-35). During the Peloponnesian War, whether or not to include metic hoplites in the general levy was again a matter for the Athenian authorities to decide. ${ }^{73}$

Were general levies compulsory already in the archaic age? If one accepts the argument of the previous section that Athens' law on astrateia went back at least as far as Solon, then it must have applied above all to the general levy, which was after all the most important form of mobilization in self-defence and in war against neighbours. Thus each naukraria will have been obliged to produce, not only a ship for naval levies and two horsemen for expeditions by land (above, p. 000), but as many hoplites and light-armed as it could muster for general levies. Even the decision whether to fight as a hoplite or as light infantry may not have been

The speaker describes multiple simultaneous crises, including threats to the grain supply (50.4-6), and says that the assembly 'voted that the trierarchs should launch the ships' (50.4 and 6): this suggests that all trierarchs and thus all available ships were mobilized. only refer to general levies; cf. Whitehead 1977, 82-6.
} 
left to individual preferences and resources but subjected to regulation, judging by the decree compelling settlers on Salamis to provide arms and armour worth at least 30 drachmas, and by Aristotle's comments on compulsory training and ownership of arms under oligarchic regimes (above, p. 000). Moreover, there is indirect evidence for this degree of public intervention also in the peculiarities of the second system of mobilization, selective conscription, to which we shall turn in the next section.

Military service in general levies was, in short, compulsory in principle but hard to enforce in practice. Especially when the militia was mobilized in a hurry, officers would have found it very hard to check that every man of the right age had turned up and was equipped as he should be. Keeping track of citizens, metics and slaves who fought as irregular light-armed and did not even operate in organized units would have been almost impossible. Yet they could exercise some control in retrospect, at least. In classical Athens, men mobilized and fought among informal peer groups of fellow-demesmen within their 'tribal' regiment, ${ }^{74}$ and in archaic Greece more hierarchical 'war bands' - rather like the band of Cimon's friends at Tanagra - may have played a similar informal part in general levies. ${ }^{75}$ Soldiers in these groups will have kept an eye on each other's performance, taking note of absences and acts of 'cowardice' as well as bravery, and they had an opportunity to bring these to the generals' attention when the army re-assembled after the campaign to sit as a court martial.

\section{Restricted military duties: 'listing' and volunteering}

Our final question is whether in the archaic age forces could be conscripted for smaller, offensive expeditions as well as general levies, or whether such campaigns relied purely on volunteers motivated by the hope of plunder or conquest, personal loyalty to a leader, or a desire to prove oneself as a warrior. At least two archaic Athenian campaigns did rely on volunteers - the (re-)conquest of Salamis around $600 \mathrm{BC}$, and the occupation of the Chersonese c. 550 - but in both cases the troops aimed to settle in conquered territory, ${ }^{76}$ so one would expect service to be on a voluntary basis. We cannot infer that this was the norm in all expeditions, and the hints in Homer that the expedition against Troy relied to some extent on compulsory mobilization (above, p. 000), suggests an alternative scenario. The first strictly contemporary evidence for selective conscription at Athens comes from Thucydides and dates to the Peloponnesian War, but the anecdotes recorded by Diodorus and cited at the start of this paper allow us to date the custom back to at least $457 \mathrm{BC}$, and the Aristotelian Athenian Constitution (26.1) assumes a still earlier origin (see above, n. 1). This is another case where the lack of direct contemporary evidence is not significant enough to infer that the system did not exist in the archaic period. We need to ask whether this type of mobilization would have been viable and useful in archaic Athens, and if so, whether any evidence implies its existence.

The process of selective conscription of fixed numbers of hoplites was called 'listing' (katalegein), denoting both selection and writing down of names. Selected hoplites served $e k$ katalogou, 'from a list' or 'by enlistment', which probably did not refer to a central register on which their names were recorded but merely to the fact that their names were put on the lists compiled for each campaign by the generals and 'tribal' commanders as they handpicked men up to the number decided by the assembly, ranging from 1,000 to 4,000 hoplites 
in the fifth century. ${ }^{77}$ These lists were posted in the agora at the monument of the 'tribal' eponymous heroes to advertise the names of the conscripted, and copies were available to the commanding officers of each tribal regiment, who at the mustering of the troops ticked the names of absentees. ${ }^{78}$ Selective conscription was thus much more tightly controlled than the typical general levy, and accordingly most of the prosecutions for astrateia of which we are aware concerned restricted mobilizations. ${ }^{79}$

Conscription did not exclude volunteering, and indeed it was thought better to volunteer for such missions than wait to be drafted, as we saw in the story of Tolmides' expedition ( $p$. 000). Volunteers in classical Athens are rarely mentioned, but it does not follow that they were rare. Aristophanes' Birds advises angry young men to channel their aggression into warfare and sign up for mercenary service or for civic garrison or campaigning duties, which implies that they had a choice and could volunteer.

'Let me give you some sound advice, young man, the kind of thing I myself learnt as a boy. Don't beat your father, but take this wing [= shield] in one hand, this spur [= spear] in the other, consider this crest a coxcomb, serve garrison duty, go on campaign, make a living in mercenary service, and let your father live. Since you are a warrior, fly off to the war in Thrace and do your fighting there.' (1362-9)

I suggest that volunteers presented themselves at an early stage and the generals placed their names on the 'lists' before making up the required numbers with conscripts. So long as volunteers formed a minority, this would be unremarkable and not enter the historical record. Accordingly, our two other references to classical volunteers concern exceptional cases in which they formed the majority of hoplites. We hear of the 3,000 volunteers for Tolmides' expedition only because he bent the rules: rather than accept only the first or best of the volunteers for a force of 1,000, he accepted them all, and drafted 1,000 conscripts in addition. Similarly, we know of volunteers in Tolmides' campaign in Boeotia a decade later only because, exceptionally, all his hoplites had volunteered. ${ }^{80}$

The same combination of conscription and volunteering is found in the recruitment of cavalry and ship's captains in classical Athens. At the start of their term of office the generals compiled a list of 400 trierarchs for that year, and although wealthy men would ideally volunteer for inclusion in the year's list the process always also involved legal coercion (ps.Xen. Ath. Pol. 3.4), initiated not only by the generals but also by enlisted captains trying to avoid service by means of the antidosis procedure. ${ }^{81}$ The cavalry commander recruited replacements for the men lost or retired from the previous year's cavalry so as to keep the total number at 1,000, and Xenophon advised him to identify suitable rich young men whom he should try to persuade to join voluntarily, but could if necessary compel by legal means (Hipparchikos 1.9-12).

For naval mobilisations short of a general levy, voluntary service was the norm, starting with the hoplites who served as marines. When Thucydides in his account of a naval action in $412 \mathrm{BC}$ says, seemingly à propos of nothing, that the 25 Athenian ships 'had marines from

See Christ 2001, 400-3 (ek katalogou as 'by enlistment'); Hansen 1985, 81-6 (ek katalogou as 'from a list'). Thucydides $2.56 .2,58.3 ; 6.31 .2$ gives 4,000 as the highest number conscripted.

As pointed out by Christ 2006, 71-2, 93, citing Pollux 8.115; Soph. fr. 144.

E.g. the expeditions to Haliartus for which Alcibiades Junior was 'listed' (Lys. 14.7; 15.11) and prosecuted, and to Tamynae by 'a small force' (Plut. Phoc. 12.1) which entailed many accusations.

Plut. Per. 18.2. This is how I would counter the objection by Christ 2006, 49 and n. 15, that there is not enough evidence to posit what he calls a 'two-track system', and that therefore 'the vast majority of hoplites ... were probably conscripts'; see n. 2, above.

See in detail Gabrielsen 1994, 43-102. 


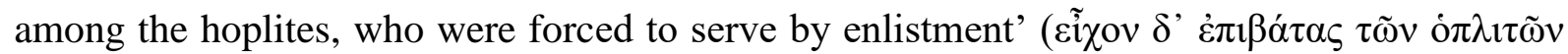
$\dot{\varepsilon} \kappa \kappa \alpha \tau \alpha \lambda o_{\gamma}$ ov $\left.\alpha v \alpha \gamma \kappa \alpha \sigma \tau o v ́ \varsigma, 8.24 .2\right)$, his purpose in mentioning this is to show what unusual and desperate measures the Athenians were forced to take at this time. Slightly earlier in the year they had introduced a law enabling them to break into the 'iron reserve', kept untouched through almost 20 years of war (8.15.1). Other texts confirm that volunteer hoplite marines, typically 10 per ship, were the norm, and that they were enrolled by the generals. ${ }^{82}$ The dozen or so sailors and 170 oarsmen required for each trireme also served on a voluntary basis, but were recruited for wages by the ship's captain; they were not necessarily citizens at all, but included resident aliens, foreign professionals, and slaves. ${ }^{83}$

In short, every citizen could volunteer for any kind of military service, the richest citizens could be compelled to serve as trierarchs and cavalrymen, and some citizens could be 'listed' to serve as hoplites. Scholars have assumed, naturally enough, that everyone who could afford hoplite arms and armour would be liable for selective conscription, just as they were liable to serve as hoplites in general levies. Yet the evidence surprisingly suggests that in classical Athens selective conscription applied only to a much smaller, richer class of men.

Aristophanes, Antiphon and Thucydides indicate that Athens' four property-classes played a role in conscription and that the lowest class, the thêtes, was exempt. The role of these classes is implied by a report that the richest two, pentakosiomedimnoi and hippeis, were granted special exemption from a general naval levy in $427 \mathrm{BC}$ (Thuc. 3.16.1), perhaps because they had paid the lion's share of a heavy war tax that year. ${ }^{84}$ The key point is that the exemption is not for 'the rich', 'tax-payers' or 'liturgists', but for particular property-classes: evidently these were meaningful categories when it came to conscription. In the same year, Aristophanes' Banqueters said that thetes 'did not serve on campaigns' (ouk estrateuonto, fr. $248 \mathrm{~K}-\mathrm{A}$ ). Since no one was exempt from general levies, in context this presumably meant either that thetes did not serve as hoplites, or that they were not liable to selective conscription. In 419 BC, Antiphon used the phrase 'to make all the thetes hoplites' (fr. 61 Thalheim): the point here is not that, unsurprisingly, many citizens were not hoplites, but that the orator used the name of the formal property-class rather than refer to 'all the poor' or 'all citizens'. It is implied that the thêtes had a different military status from the higher property-classes. ${ }^{85}$ Finally, Thucydides distinguished two kinds of Athenian hoplites mustered in 415 BC: those recruited 'by enlistment' (ek katalogou) and thètes who served as marines (6.43.1). He might have simply contrasted conscripted regular hoplites and volunteer marines, but by adding that marines came from the lowest property-class he implied that conscripted hoplites came from the higher classes. Evidently, at least some thêtes did own hoplite equipment, so that they were able to volunteer for service as marines, ${ }^{86}$ but unlike the higher classes they were not liable to service by 'listing'. ${ }^{87}$

This may seem odd, but there is further evidence that not all men able to afford hoplite service were actually liable to selective conscription: the level of wealth below which one

$I G \mathrm{I}^{3} 60$ (c. $430 \mathrm{BC}$ ): generals to recruit 150 volunteers, almost certainly 5 marines per ship; Thuc. 6.43.1: marines not 'by enlistment', i.e. volunteers (see below); ML 23.23-7 (Themistocles Decree, 480 BC, if genuine): generals mobilize marines and archers separately from rest of crew.

E.g. Gabrielsen 1994, 107-9; Morrison et al. 2000, 114-18.

As suggested by Van Wees 2013b, 96.

These fragments of Antiphon and Aristophanes come from Harpocration, s.v. thētes kai thētikon.

The suggestion that marines (unlike any other fifth-century Athenian hoplites) 'may well have been given their armour by the state' (de Ste. Croix 2004, 21) is highly unlikely; fighting as a marine required special skill and could not have been left to men who did not even own the equipment.

Rosivach 2002b; Gabrielsen 2002 try to explain away the evidence (except Thuc. 6.43.1). De Ste. Croix 2004,27 , objects to a lack of evidence for quantitative property qualifications: see below. 
belonged to the thetes was much higher than one might have expected. The threshold for the third class, the zeugitai, 'yoke-owners', ${ }^{88}$ was set at an annual harvest of 200 medimnoi. If this was the typical Athenian crop of barley, it required 13.8 ha of land, worth 7,590 dr., much more than one needed for keeping a yoke of plough oxen, and three times as much as necessary to be able to afford hoplite equipment. A property of this size would be large enough for the owner to qualify as a member of the 'leisure class'. We may estimate that only about $15 \%$ of the classical Athenian citizen population would have such properties, whereas about $40 \%$ could afford to serve as hoplites. ${ }^{89}$

Some scholars have concluded either that our sources must be wrong about the property threshold or else that property classes were not linked to military obligations after all, on the grounds that Athens would have wanted to be able to mobilize as many hoplite soldiers as possible, not just large land-owners. ${ }^{90}$ Yet the implication that the thetes included many men who could afford hoplite service but were not liable for selective conscription fits neatly with Thucydides' testimony that in his day many thêtes - at least 2,000 ${ }^{91}$ - owned hoplite equipment but served only on a voluntary basis. There are other pointers, too, to the high economic status of hoplites conscripted by 'listing', starting with the striking assumption that all conscripted hoplites would bring a personal (slave) attendant on campaign (Thuc. 3.17.4) and the belief that service 'by enlistment' caused disproportionate numbers of casualties among 'the wealthy'. ${ }^{92}$ The fact that conscripted levies were very much smaller than general levies - at most 4,000 when Athens had 13,000 hoplites aged 20-39, and more typically only 1,000-2,000 men - is significant.

Also telling is Aristotle's conception of an ideal state in which only hoplites have citizen rights, but not all hoplites do: instead he recommends setting a property threshold 'as high as possible' while still including just over half the male population. Whatever he has in mind exactly, Aristotle's scheme implies that the citizenship property requirement should be set higher than the minimum necessary for hoplite service, and he goes on to spell out that the excluded will still be able and willing to serve as hoplites if treated well and given pay. ${ }^{93}$ The distinction made by Aristotle, between richer hoplites who deserved to share political power and poorer hoplites who did not, was anticipated by the oligarchs who took power at Athens in $411 \mathrm{BC}$. They proposed to share power with only 5,000 hoplites, at a time when Athens must still have had 9,000 hoplites at the very least. ${ }^{94}$

Down to at least $415 \mathrm{BC}$, then, the property-classes apparently played a role in assigning military obligations, and drew a line between what one may call 'leisure-class hoplites' and 'working-class hoplites', between hoplites of the highest three property-classes who were liable for selective conscription, and hoplites among the thetes who were not. What was the rationale for this distinction? Since selective conscription was typically used for longer

For this meaning of the name, see Van Wees 2006b, 352-60; Duplouy 2014, 650-1; contra Whitehead 1981 , who argued for 'yoked men', meaning hoplites 'yoked' in the phalanx.

See Van Wees 2013a, 229-32; 2006b; 2001; Foxhall 1997, 129-32. Leisure class: Davies 1981, 28-9.

De Ste. Croix 2004, 47-8, notes the problem (with Boeckh 1886, 581) and concludes that the property qualifications must be wrong (cf. Rosivach 2002a; Gabrielsen 2002, 95-8). Rosivach 2002b; Gabrielsen 2002, 92-4 reject any link between property-class and military service. Others conclude that the qualifications must represent a later raising of the threshold: Raaflaub 2006 (c. 460 BC); Valdés Guía and Gallego 2010, 270-7 (c. 400 BC).

Since Athens could muster more than 200 ships with 10 hoplite marines each.

Arist. Pol. 1303a8-10; Ath. Pol. 26.1 speaks instead of casualties among 'the decent folk among both the people and the wealthy', so assumes either wider conscription or extensive volunteering.

Arist. Pol. 1297b2-6; see discussion in Van Wees 2001, 57-8.

See Thuc. 8.65.3; Ath Pol. 29.5; Lysias 20.13, with Van Wees 2001, 56-7. 
campaigns overseas, one might argue that only members of the leisure class could afford to serve on such campaigns. But even in the archaic age naval crews probably did not have to serve at their own expense, in view of the existence of a dedicated fund 'for the naukraroi' which will have paid for their maintenance, while in the classical period all who served on overseas expeditions received a wage in silver coin. ${ }^{95}$ Another possibility might be that the obligation to serve on campaigns other than general levies was imposed on the rich as an extra liability, just as liturgies and ad hoc war taxes were imposed only on the rich. Against this, however, counts the ancient view that 'the poor' in Athens did not see overseas expeditions as a liability but as an opportunity to earn pay and other rewards which they were keen to enjoy themselves. ${ }^{96}$ Since it would have been in Athens' interest to make as many men as possible liable for hoplite service, I would argue, rather, that a system which confined this liability to the leisure classes must have been introduced at a time when only the leisure classes were able to serve as hoplites.

The institution or reform of the property-class system is attributed to Solon, and according to our sources the central problem which faced Solon was extreme inequality of wealth: 'all the land was in the hands of a few' (Ath. Pol. 2.2; 4.5). Since Solon emphatically did not resort to a general redistribution of land, even after his reforms relatively few men must still have owned a great deal of land and the majority very little. In other words, there was no significant class of 'middling' farmers but a sharp polarization between rich and poor. ${ }^{97}$ This situation explains the high property threshold: immediately below it, where one might have found middling men who could also afford to serve as hoplites, there was simply a wide gap in the early sixth century, and below that gap only men who were too poor to serve, thètes in the literal sense of the word, 'hired labourers'. In Solon's day, unlike in the fifth century, the high property-threshold thus made perfect sense and imposed liability for hoplite service on everyone who could afford it.

When social and economic developments from the second half of the sixth century onwards created a middling class of farmers, as well as craftsmen and traders, there were increasingly many thêtes who could afford to serve as hoplites, ${ }^{98}$ but the system did not need to be changed, because they would simply take part in general levies along with everyone else and they could take part in selective levies by volunteering. The presence of 'poor' Socrates at the siege of Potidaea and the battle of Amphipolis may be an example of the latter. Moreover, naval campaigns often involved only the normal trireme crews which were recruited on a voluntary basis; where they did involve additional selective conscription of hoplites they were usually, for the most of the fifth century, so successful that few of the rich will have complained when they were occasionally forced to serve. As soon as the Peloponnesian War began to take its toll, however, the system began to meet resistance. In 427, the comment that the thêtes 'did not serve on campaign' was surely made as part of a complaint that their exemption for selective conscription was unfair. The proposal in 419 'to make all the thêtes hoplites' suggests a plan to change the military role of property classes.

After 415, this military function disappears from our record altogether. Significantly, the oligarchs of 411 no longer used the property-class system to select their richer 5,000 hoplites. The reason was probably that the property classes were defined entirely in terms of landownership and that this was no longer an adequate basis for distinguishing between rich and poor by the late fifth century: a proposal to restrict citizen-rights to landowners in $403 \mathrm{BC}$

See Van Wees 2013b, 41-2, 70-3.

E.g. Thuc. 6.24.3-4; Ath Pol. 24.1.

For full discussion, see Van Wees 1999; 2006b; 2013a.

See in more detail Van Wees 2013a, esp. 236-40; 2013b, esp. 128-33. 
(Dion. Hal. Lys. 32) was rejected because this would have excluded 'many horsemen and hoplites' (Lys. 34.4). Accordingly, we no longer hear of the property classes playing a military role in the fourth century, and they also came to be ignored as a qualification for political office, even though they did continue to exist as a legal category. ${ }^{99}$ As in the case of military legislation, therefore, we have an institution plausibly associated with Solon which is still attested in the late fifth century but then falls into disuse.

Along the same lines, the two highest property classes do not seem to have had a distinct military role in the fifth century, but they may well have done under Solon. The second class consisted of hippeis, 'horsemen', after all, and their property threshold will have coincided with the ability to keep at least one horse. Before the introduction of state subsidies in the mid-fifth century, this meant that only the top two classes could be liable for cavalry service. A link between liability to serve as trierarch and membership of the highest class is not mentioned by any classical source, yet it is probably no coincidence that this class was defined, as its name pentakosiomedimnoi implies, by ownership of enough land to produce an annual harvest of 500 medimnoi of barley: the value of such an estate can be calculated at about 3 talents, which was also the estimated property value which made a citizen liable to service as a trierarch in the fourth century. ${ }^{100}$ There was thus at least a rough, de facto, correlation between property classes and military obligations, and this connection may have been a formal part of the system as originally conceived by Solon.

Alain Duplouy and others have argued that the archaic 'property classes' were merely a set of informal social distinctions that did not entail formal rights or duties, only moral claims and expectations. ${ }^{101}$ It is indeed likely that the 'horsemen', 'yoke-men' and 'hired men' derived their names from pre-existing informal labels designating respectively land owners rich enough to keep a horse or a yoke of plough-oxen, and a mass of men who owned too little land to be fully independent and therefore worked as hired farm hands. But the pentakosiomedimnoi do not fit this mould. Duplouy suggests that this, too, was an informal label, like geōmoroi, 'land-sharers', which elsewhere denoted a land-owning elite. But nowhere else do we find differentiation between two levels of the rich: we find either 'landsharers' or 'horsemen', not both. Nor is there any other instance of an elite with a name as precise and unwieldy as 'five-hundred-bushel-men'. Everything suggests that this label was an artificial and formal additional distinction established amongst an elite that had previously been known simply as 'Horsemen', as in neighbouring Eretria and Chalcis. ${ }^{102}$ Moreover, it is not likely that the three lower classes remained vague 'social' labels when the new upper property-class was so precisely defined: surely formal property thresholds were also set for these classes when the category of 'five-hundred-bushel-men' was introduced. Since the latter are attested in Solonian laws, we may conclude that formal property classes were indeed created by Solon, if not earlier.

Our sources do not explicitly credit Solon with assigning military duties to his property classes, so in theory the obligations might have been added later - though not as late as the fifth century, when, as I argued above, they were already out of synch with economic realities. In practice the silence of our sources is likely due to their exclusive focus on the political

Ath. Pol. 7.4 (ignored in fourth century); for continuing legal role see de Ste. Croix 2004, 8-13.

See Van Wees 2013a, 230-1: 500 medimnoi of barley weighed 13,750 kg, which required 17.2 ha (assuming a high barley yield for Attica of $800 \mathrm{~kg} / \mathrm{ha}$ ), which needs to be doubled for biennial fallow, i.e. 34.4 ha or 378 plethra, at a minimum price of $50 \mathrm{dr}$. per plethron: 18,920 dr. For the estimated 'liturgical census', see Davies 1971, 20-4; Gabrielsen 1994, 45-53.

Duplouy 2014; de Ste. Croix 2004, 7, 48 ('military and social groups that already existed in Solon's day'); Rosivach 2002a, 39-47.

As noted by de Ste. Croix 2004, 49, who however rejects formalization of the remaining classes. 
dimensions of Solon's system, and it seems obvious that duties and rights must have been part of the same package. Only if political privileges were balanced by military (and fiscal) obligations could one be confident that citizens would not claim higher status than they deserved, especially since this was probably a matter of self-assessment. Liability for military service was thus in all likelihood already part of Solon's original system, which set not only formal property thresholds, but also dictated that all those above the lowest threshold of 200 medimnoi were obliged to keep a set of hoplite arms and armour, and serve with this equipment whenever required. At the two higher levels, one could be required from time to time to provide in addition a horse or a ship, respectively, but not everyone was required to maintain cavalry horse or warship permanently.

In principle, it is possible that under Solon the obligation of the leisure classes to serve as hoplites was only enforced for general levies, and that select expeditions still relied exclusively on volunteers. It has been suggested, moreover, that it would have been impossible to enforce (selective) conscription without formal records of who was liable, and that the citizen registers which seem to have functioned as such in the classical period were kept by the demes, which only acquired such administrative roles after Cleisthenes' reforms. ${ }^{103}$ However, we have a clue to the earlier existence of citizen lists in the peculiar name of the classical deme registers, lexxiarchika grammateia, and we also have some reason to think that there were not always enough volunteers for early Athenian campaigns.

That deme records were called 'lexiarchic registers' puzzled ancient lexicographers, and they tried to explain this name from the etymology of lexxis, 'something that falls to one, by lot or by right' (from the verb lanchanō). They concluded that these were either lists of men who 'ruled' their 'allotment', i.e. were in charge of their inherited estate, or lists of men among whom 'rule' was 'allotted', i.e. were eligible to hold magistracies. ${ }^{104}$ Modern scholars have tended to favour the first option, but both are clearly mere guesses, and it is in fact clear from contemporary evidence that the classical registers included every male citizen from the age of 18, not just property owners or potential officeholders. ${ }^{105}$ As Henri van Effenterre pointed out long ago, the 'lexiarchic registers' are simply 'the registers of the lexiarchoi' $(1976,13)$, the lexiarchs being an obscure body of 6 officials whose only attested classical role is to regulate attendance in the assembly, with the help of 30 citizen assistants and the famous Scythian archers. ${ }^{106}$ If the deme registers were called 'lexiarchic', it must be because they had once upon a time been maintained by the lexiarchs, and that time must have been before the reforms transferred this responsibility to the demes. Already in archaic Athens before Cleisthenes, formal written citizen lists thus existed, and were kept by a board of lexiarchs. ${ }^{107}$ As Van Effenterre also pointed out, the only other Athenian board of 6 was that of the thesmothetai, established by Solon according to our sources (1976, 13-14), and certainly of archaic date. It seems reasonable to infer that the lexiarchs also went back to Solon and were

These are the arguments of Frost 1984, adopted by many since; see n. 4, above.

Control of property: Harpocration s.v. lēxiarchika grammateia: lēxeis are klèroi and ousiai; Photius s.v. lēxiarchika grammateia (1) $=$ Suda $\lambda$ 463. Eligibility for magistracies: Photius s.v. lexxiarchika grammateia $(2)=$ Suda $\lambda 462$.

See Whitehead 1986, 35-6 n. 130; Fisher 2001, 142-3. ML 23.29-31; [Dem.] 50.6 show use for naval mobilization and imply that even poor citizens were included; $I G \mathrm{I}^{3}$ 138.1-7 suggests a military connection; Aeschin. 1.18, 103; Lyc. 1.76 show citizens were registered at 18; see also Isae. 7.26; Isoc. 8.88; Dem. 44.35-7; 57.26, 60.

Pollux 8.104; see also Hesychius and Photius s.v. triakonta, who cite as evidence 'Phrynichus', probably the fifth-century comic poet, though the fragment is not included in Kassel-Austin 1989.

It seems to me more likely that the lexiarchs operated as a board and were collectively responsible for the citizens' lēxeis than that they were each 'leader of a lēxis' as Van Effenterre suggests; he imagines lèxeis as 'sections, ranks, age-classes or social groups' (14). 
'in charge of what is allotted', i.e. responsible for making sure that citizens received the rights and fulfilled the duties assigned to them by Solon's system of property-classes. ${ }^{108}$

Not only would conscription thus have been viable, but it may well have seemed necessary even in the early sixth century, in view of the difficulty the Athenians experienced in the wars they fought at the time. Solon may have (re)conquered Salamis with the aid of 500 volunteers, but tradition also claimed that this happened only after many defeats and after Solon famously composed a song in which he exhorted the Athenians to fight for the island and not to live with the 'shame' of being 'Salamis-losers'. ${ }^{109}$ Evidently volunteers did not always line up for hard-fought wars and modest rewards. The initial conquest and settlement of Sigeion shortly before Solon's time was probably also achieved by volunteers, but for many decades afterwards Athens remained embroiled in wars to defend or reconquer the city from Mytilene, and it seems less likely that there were always volunteers for these. ${ }^{110}$ Similarly, it was Athenian volunteers who occupied the Chersonese, but we have to wonder whether Peisistratus' imposition of regime change in Naxos at around the same time would equally have been achieved by Athenian volunteers, or mercenaries, alone. ${ }^{111}$ At a minimum, we may note that in Solon's lifetime Athens fought two wars which proved hard to win, and that this could easily have provided a stimulus to introduce, if it did not exist already, conscription for selective campaigns as well as general levies.

In sum, volunteering was always important to Athenian armies and especially fleets, and like service in general levies it provided opportunities not only for citizens, rich and poor, but also for foreigners (in the navy) and slaves (as oarsmen and personal attendants) to 'perform' and assert or enhance their status. But from Solon onwards at least, the city also had the option of resorting to selective conscription of hoplites, and this was a matter of strict legal obligation for the leisured elite which occupied the three highest property-classes, an obligation which a commander, if he wanted to, could enforce with the aid of lexiarchic registers, mobilisation rosters and prosecution in the soldiers' court.

\section{Conclusion: citizens and soldiers under Solon}

'The political community must consist exclusively of those who have the military equipment' (Arist. Pol. 1297b1). A simple rule applies in the ideal city of classical Greek political theory: all citizens are obliged to be soldiers and only citizens are allowed to be soldiers. The realities of military service in the classical period are hard to discern behind this ideological screen, and they are positively obscure in earlier ages, but a close look at the evidence reveals wider participation in war in the classical period than the philosophical ideal suggests, and more complex, formal regulation of military obligations in the archaic age than recent scholarship has been inclined to imagine. Classical military institutions in fact provide

This implies that the lexiarchic registers included an indication of property class, which in view of the significance of property classes they surely must have done even in the fifth century (cf. Ath. Pol. 26.2 and $I G \mathrm{I}^{3} 46.43-6$ for the significance of property classes in 457 and c. 445 respectively). There is some indirect evidence for this in the Aristotelian Oikonomika 1347a18-24 (2.2.5): among Athenian colonists at Potidaea taxable wealth was registered 'by individual property, in whatever place it was located' rather than 'all together in each man's own deme'; the latter was evidently the (Athenian) norm. Athens controlled Potidaea from 429-405 and 362-351 BC, but since eisphora taxes were collected by symmories rather than demes after $377 \mathrm{BC}$, it must in fact be the earlier date.

109 Plut. Solon 9 and Solon $f r$. 1-3 West. The alternative tradition that Salamis was conquered by a single triaconter and a fishing fleet (Plut. Solon 9.1-3) was an etymological folktale and cannot be treated as evidence for early Athenian warfare: see Van Wees 2013b, 59.

110 Hdt. 5.95; cf. Alcaeus fr. 167, 428 L-P; Strabo 13.1.38-9; Plut. Mor. 858ab; Diog. Laert. 1.74.

111 Naxos: Hdt. 1.64.2; Ath. Pol. 15.3. 
important clues to the nature of their archaic predecessors because some of the practices attested during the Peloponnesian War prove to be, not newly sophisticated institutions, but relics of the Solonian system, which duly disappear in the fourth century.

It seems very likely that private raiding, informal war bands, personal loyalties and voluntary military service played an even more prominent role in archaic Greece than they did later, but it would be wrong to assume that there were not also communal wars and compulsory service. We find signs of the latter already in Homer, and at Athens Solon instituted, or indeed merely reformed, a complex institutional framework for public warfare. He obliged the leisured elite, which made up the three highest property classes, to serve as hoplites whenever required by the state - making it a crime to abandon one's arms and armour to the enemy, and perhaps also setting a minimum value for the equipment (above, $\mathrm{p}$. 000) - while obliging all other citizens to serve in levies 'with the whole community' in whatever capacity they could afford. Levies were organized by administrative districts called naukrariai, which could also demand ships and horses from the two richest property-classes. Solon may have instituted a board of 'lexiarchs' to record and monitor the different obligations and rights allocated to the property classes, and he almost certainly provided a new, public, legal procedure to punish lapses from military duty.

Cleisthenes' reforms transferred most of the responsibilities of naukraroi and lexiarchs to the demes, and created new military units and commanders, but appears not to have touched the military dimension of the property classes or the military laws of Solon, both of which we still find in place in the early stages of the Peloponnesian War. Social and economic developments since the late sixth century, however, had caused the property-class system to fall out of line with the realities of property-ownership, no longer exclusively in land, and no longer as polarized as it had been under Solon. At the same time, political developments meant that Solon's military laws were no longer congenial to the new democratic culture. Perhaps by the latter part of the Peloponnesian War, and certainly by the early fourth century, the Solonian system was therefore largely abandoned or no longer enforced, although we cannot easily discern the stages by which this happened. The mobilization of general levies of all citizens and other residents, unjustly neglected by modern scholars, is the one thing that continued in essentially the same form throughout.

The evidence for all the above is of course precarious but it seems to me important that we do not simply reject it out of hand, especially not on the currently common assumption that archaic Greece could not have known the degree of formalization, institutionalization and state-formation that the sources seem to indicate. We cannot assume a priori that archaic Greece was either a complex or a simple world, but must be guided by what the written and material evidence tells us. In the case of military obligations, it tells us that volunteering for service and conspicuous display of military status, undoubtedly vital parts of archaic civic life, took place within an institutionalized framework; indeed, a framework that was in some respects more institutionalized than it came to be under the democracy of classical Athens.

This brings us at last to an answer to our fundamental question: to what degree was the archaic citizen-body a formal juridical 'order' with legally enforceable rights and duties, or rather an informal 'status group' defined by peer judgement of one's 'performance', with moral but not legal obligations and privileges? As we have interpreted the Solonian system, the top three property classes did form a set of distinct juridical orders of citizens, with formal qualifications and strictly defined, publicly enforced, military obligations (as well as fiscal obligations and political privileges). The lowest property class, by contrast, did not constitute such an order, at least so far as military duties were concerned: it was obliged to serve in a general levy, but so were non-citizens, and it had no legal military obligations beyond this (or 
fiscal obligations, or political rights beyond attending assembly and popular court). For the lower classes, therefore, citizen status in important respects remained fluid and informal, and needed to be asserted by 'performing' in war and other arenas.

\section{Bibliography}

Andrewes, A. (1981), 'The hoplite katalogos', in G. Shrimpton \& D. MacCargar, eds, Classical Contributions: studies in honor of M.F. McGregor (New York), 1-3.

Best, J. (1969), Thracian Peltasts and their Influence on Greek Warfare (Groningen)

Blok, J.H. and A.P.M.H. Lardinois, eds. (2006), Solon of Athens. New historical and philological approaches (Leiden).

Boeckh, A. (1886), Die Staatshaushaltung der Athener. Erster Band. Third ed. (Berlin).

Cairns, D. (1993), Aidos: the psychology and ethics of honour and shame in ancient Greek literature (Oxford).

Carey, C. (1989), Lysias. Selected Speeches (Cambridge).

Christ, M. (2001), 'Conscription of hoplites in classical Athens', $C Q$ 51, 398-422.

Christ, M. (2006), The Bad Citizen in Classical Athens (Cambridge).

Crowley, J. (2012), The Psychology of the Athenian Hoplite (Cambridge).

Davies, J.K. (1971), Athenian Propertied Families 600-300 BC (Oxford).

Davies, J.K. (1981), Wealth and the Power of Wealth in Classical Athens (New York).

Ducat J. (2006), Spartan Education (Swansea).

Duplouy, A. (2006) Le prestige des élites. Recherches sur les modes de reconnaissance sociale en Grèce entre les $X^{e}$ et $V^{e}$ siècles avant J.-C (Paris).

Duplouy, A. (2014), 'Les prétendues classes censitaires solonienne. À propos de la citoyenneté athénienne archaïque', Annales. Histoire, Sciences Sociales 69, 629-58.

Echeverría, F. (2008), Ciudadanos, campesinos y soldados el nacimiento de la 'pólis' griega y la teoría de la 'revolución hoplita'. Anejos de Gladius 12 (Madrid).

Echeverría, F. (2012), 'Hoplite and phalanx in archaic and classical Greece : a reassessment', Classical Philology 107, 291-318

Fawcett, P., forthcoming 2016, 'xxxx', Hesperia, xxx-xx.

Figueira, T.J. (2011), 'The Athenian naukraroi and archaic naval warfare', Cadmo 21, 183-210.

Finley, M.I. (1973), The Ancient Economy (London; revised ed. 1985).

Fisher, N. (2001), Aeschines. Against Timarchos (Oxford).

Foxhall, L. (1997), 'A view from the top: evaluating the Solonian property classes', in L. Mitchell and P.J. Rhodes, eds., The Development of the Polis in Archaic Greece (London), 39-48.

Frost, F. (1984), ‘The Athenian military before Cleisthenes', Historia 33, 283-94.

Frost, F. (2005), Politics and the Athenians. Essays on Athenian history and historiography (Toronto). 
Gabrielsen, V. (1985), 'The naukrariai and the Athenian navy', $C \& M 36,21-51$.

Gabrielsen, V. (1994), Financing the Athenian Fleet (Baltimore).

Gabrielsen, V. (2002), 'The impact of armed forces on government and politics in archaic and classical Greek poleis: a response to Hans van Wees', in A. Chaniotis and P. Ducrey (eds.), Army and Power in the Ancient World (Stuttgart), 83-98.

Gabrielsen, V. (2007), 'Warfare and the state', in P. Sabin et al., eds., The Cambridge History of Greek and Roman Warfare, Vol. I (Cambridge), 248-72.

Gomme, A.W. (1945), A Historical Commentary on Thucydides, Vol. I (Oxford).

Gomme, A.W., Andrewes, A. and Dover, K.J. (1970), A Historical Commentary on Thucydides, Vol. IV (Oxford).

Haas, C.J. (1985), 'Athenian naval power before Themistocles', Historia 34, 29-46.

Hale, J. (2009), Lords of the Sea: the epic story of the Athenian navy and the birth of democracy (New York).

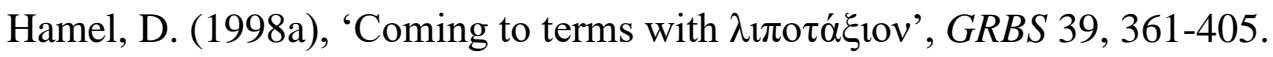

Hamel, D. (1998b), Athenian Generals: military authority in the classical period (Leiden).

Hansen, M.H. (1981), 'The number of Athenian hoplites in 431 BC', SO 56, 19-32.

Hansen, M.H. (1985), Demography and Democracy. The number of Athenian citizens in the fourth century (Herning).

Hansen, M.H. (1988), Three Studies in Athenian Demography (Copenhagen).

Harding, P. (2008), The Story of Athens. The fragments of the local chronicles of Attica (Abingdon).

Hornblower, S. (2000), 'Sticks, stones and Spartans. The sociology of Spartan violence', in H. van Wees, ed., War and Violence in Ancient Greece (Swansea), 57-82.

Hunt, P. (1998), Slavery, Warfare and Ideology in the Greek Historians (Cambridge).

Jones, A.H.M. (1957), Athenian Democracy (Oxford).

Lendon, J.E. (2005), Soldiers and Ghosts. A history of battle in classical antiquity (New Haven).

Lipsius, J.H. (1905), Das attische Recht und Rechtsverfahren, vol. I (Leipzig).

MacDowell, D.M. (1962), Andocides On The Mysteries (Oxford).

Meiggs R. and Lewis, D. (1988) A Selection of Greek Historical Inscriptions to the End of the Fifth Century BC. Revised Edition (Oxford).

Morrison, J. et al. (2000), The Athenian Trireme. Second edition (Cambridge).

Ober, J. (1993), 'The Athenian Revolution of 508/7 BC: violence, authority and the origins of democracy', in C. Dougherty and L. Kurke, eds., Cultural Poetics in Archaic Greece (Cambridge), 215-32. (Reprinted in J. Ober, The Athenian Revolution, Princeton 1996, 32-52).

Osborne, R. (1985), Demos: the discovery of classical Attica (Cambridge).

Pritchard, D.M. (2010), 'The symbiosis of democracy and war: the case of ancient Athens', in D.M. Pritchard, ed., War, Democracy and Culture in Classical Athens (Cambridge), 1-62.

Raaflaub, K. A. (2006), 'Athenian and Spartan Eunomia, or: What to do with Solon's timocracy?', in Blok and Lardinois (eds.), 390-428.

Rhodes, P.J. (2013), 'The organisation of Athenian public finance', $G \& R$ 60, 203-31.

Roisman, J. (2005), The Rhetoric of Manhood. Masculinity in the Attic orators (Cambridge). 
Rosivach, V.J. (2002a), 'The requirements for the Solonic classes in Aristotle, AP 7.4', Hermes 130, $36-47$.

Rosivach, V.J. (2002b), 'Zeugitai and hoplites', $A H B$ 16, 33-43.

Saunders, T.J. (1991), Plato's Penal Code (Oxford).

Schubert, C. (2008), 'Die Naukrarien: zur Entwicklung der attischen Finanzadministration', Historia 57.1, 38-64.

Schwartz, A. (2009), Reinstating the Hoplite. Arms, armour and phalanx fighting in archaic and classical Greece. Historia Einzelschriften 207 (Stuttgart).

Schwertfeger, T. (1982), 'Der Schild des Archilochos', Chiron 12, 253-80.

Ste. Croix G.E.M. de (2004) Athenian Democratic Origins Origins and Other Essays (Oxford).

Thalheim, T. (1877), 'Das attische Militärstrafgesetz und Lysias 14,7', Neue Jahrbücher für Philologie und Paedagogik, 269-72.

Todd, S.C. (2000), Lysias (Austin).

Valdés Guía, M. and J. Gallego (2010), 'Athenian zeugitai and the Solonian census classes: new reflections and perspectives', Historia 59.3, 257-81.

Van Effenterre, H. (1976), 'Clisthène et les mesures de mobilisation', REG 89, 1-17. (Reprinted in H. Van Effenterre, Minos et les Grecs. La cité revisitée, Paris 2013, 643-759.)

Van Wees, H. (1999), 'The mafia of early Greece: violent exploitation in the seventh and sixth centuries BC', in K. Hopwood, ed., Organized Crime in Antiquity (London and Swansea), 151.

Van Wees, H. (2001), 'The myth of the middle-class army', in T. Bekker-Nielsen and L. Hannestad, eds., War as a Cultural and Social Force (Copenhagen), 45-71.

Van Wees, H. (2004), Greek Warfare: myths and realities (London).

Van Wees, H. (2006a), 'The oath of the sworn bands. The Acharnae stela, the Oath of Plataea and archaic Spartan warfare', in A. Luther et al., eds., Das frühe Sparta (Stuttgart), 125-64.

Van Wees, H. (2006b), 'Mass and elite in Solon's Athens: the property classes revisited', in Blok and Lardinois (eds.) 2006, 351-89.

Van Wees, H. (2008), "Stasis, destroyer of men": mass, elite, political violence and security in archaic Greece', in C. Brélaz and P. Ducrey (eds.), Sécurité collective et ordre public dans les societies anciennes (Vandoeuvres-Geneva), 1-48.

Van Wees, H. (2011), 'The "law of hybris" and Solon's reform of justice', in S.D. Lambert (ed.), Sociable Man. Essays on ancient Greek social behaviour, in honour of Nick Fisher (Swansea), 117-44.

Van Wees, H. (2013a), 'Farmers and hoplites: models of historical development', in D. Kagan and G. Viggiano, eds., Men of Bronze. Hoplite warfare in ancient Greece (Princeton), 222-55.

Van Wees, H. (2013b), Ships and Silver, Taxes and Tribute: a fiscal history of archaic Athens (London)

Van Wees, H., forthcoming, 'Luxury, austerity and equality'/'The common messes', in A. Powell, ed., A Companion to Sparta (Maldon).

Wallinga, H.T. (2005), Xerxes' Greek Adventure (Leiden and Boston).

Welwei, K.W. (1974), Unfreie im antiken Griechenland, vol. I: Athen und Sparta (Wiesbaden). 
Whitehead, D. (1977), The Ideology of the Athenian Metic. Cambridge Philological Society, Supplement 4 (Cambridge).

Whitehead, D. (1981), 'The archaic Athenian zeugitai', $C Q$ 31, 282-86.

Whitehead, D. (1983), 'Competitive outlay and community profit: philotimia in classical Athens', $C \& M 34,55-74$.

Whitehead, D. (1986), The Demes of Attica, 508/7-c.250 BC. A political and social study (Princeton).

Whitehead, D. (2001), Aeneas Tacticus: How To Survive Under Siege. Second edition (Bristol). 